\title{
Biophysical Characterization of Functionalized Titania Nanoparticles and Their Application in Dental Adhesives
}

\author{
Jirun Sun ${ }^{1 *}$, Elijah J. Petersen ${ }^{2}$, Stephanie S. Watson ${ }^{3}$, Christopher M. Sims ${ }^{2}$, Alexander Kassman ${ }^{1}$, \\ Stanislav Frukhtbeyn ${ }^{1}$, Drago Skrtic ${ }^{1}$, Meryem T. Ok ${ }^{2}$, Debbie L. Jacobs ${ }^{3}$, Vytas Reipa ${ }^{2}$, Qiang Ye ${ }^{4}$, and \\ Bryant C. Nelson ${ }^{2 *}$
}

1. Volpe Research Center, American Dental Association Foundation, Gaithersburg, MD 20899, USA

2. Biosystems and Biomaterials Division, Material Measurement Laboratory, National Institute of Standards and Technology, Gaithersburg, MD 20899, USA

3. Polymeric Materials Group, Materials and Structural Systems Division, Engineering Laboratory, National Institute of Standards and Technology, Gaithersburg, MD 20899, USA

4. Bioengineering Research Center, University of Kansas, Lawrence, Kansas 66045, USA

\section{* To whom correspondence should be addressed:}

bryant.nelson@nist.gov

$\underline{301-975-2517(\mathrm{ph}) ; 301-975-8542(\mathrm{fax})}$

jirun.sun@nist.gov

$\underline{301-975-5439(\mathrm{ph})}$ 


\begin{abstract}
:
It is demonstrated that carboxylic acid-functionalized titanium dioxide $\left(\mathrm{TiO}_{2}\right)$ NPs produce significantly higher levels of reactive oxygen species (ROS) after visible light irradiation (400 nm to $800 \mathrm{~nm}, 1600$ $\mathrm{mW} / \mathrm{cm}^{2}$ ) in comparison to nonfunctionalized $\mathrm{TiO}_{2}$ NPs. The level of ROS produced under these irradiation conditions was not capable of generating oxidatively induced DNA damage in a cell-free system for $\mathrm{TiO}_{2}$ concentrations of $0.5 \mathrm{mg} / \mathrm{L}$ or $5 \mathrm{mg} / \mathrm{L}$. In addition, specific incorporation of the acrylic acid-functionalized $\mathrm{TiO}_{2} \mathrm{NPs}$ into dental composites allowed us to utilize the generated ROS to enhance photopolymerization (curing and degree of vinyl conversion (DC)) of resin adhesives and create mechanically superior and biocompatible materials for dental applications. Incorporation of the $\mathrm{TiO}_{2} \mathrm{NPs}$ into selected dental composites increased the mean DC values by $\approx 7 \%$. The modified $\mathrm{TiO}_{2}$ materials and dental composite materials were extensively characterized using thermogravimetric analysis, electron microscopy, Fourier transform infrared spectroscopy, and electron paramagnetic resonance. Notably, dental adhesives incorporated with acrylic acid-functionalized $\mathrm{TiO}_{2} \mathrm{NPs}$ produced stronger bonds to human teeth following visible light curing in comparison to traditional dental adhesives not containing NPs with an increase in the shear bond strength of $\approx 29 \%$. In addition, no leaching of the incorporated NPs was detectable from the dental adhesives after 2500 thermal cycles using inductively coupled plasma-optical emission spectroscopy, indicating that biocompatibility of the adhesives was not compromised after extensive aging. These findings suggest that NP-induced ROS may be useful to produce enhanced nanocomposite materials for selected applications in the medical device field.
\end{abstract}

Keywords: dental resins; DNA damage; titanium dioxide; nanoparticles; reactive oxygen species 


\section{Introduction}

The unique physical and chemical properties of engineered nanoparticles (NPs) has resulted in their usage in a wide range of consumer products. One of these unique properties is that some NPs, such as titanium dioxide nanoparticles $\left(\mathrm{TiO}_{2} \mathrm{NPs}\right)$, are inherently photoactive and are capable of generating reactive oxygen species (ROS) [1-3]. When $\mathrm{TiO}_{2} \mathrm{NPs}$ are irradiated with photons having energies larger than the $\mathrm{TiO}_{2}$ bandgap $\left(\mathrm{E}_{\mathrm{g}}>3 \mathrm{eV}\right)$, electron/hole pairs form in the crystal lattice and different types and levels of ROS can be produced from the reactions of electron/hole pairs with the surrounding medium [46]. Because these ROS are strong oxidants, $\mathrm{TiO}_{2}$ NPs have been used in diverse applications: selfcleaning surfaces $[7,8]$, resin-based nanocomposites as reinforcing additives and co-initiators during photo-polymerization [9-13] and in the development of antibacterial medical devices [14-16]. There have been concerted research efforts directed toward improving the overall performance of dental materials through the selective incorporation of $\mathrm{TiO}_{2}$ NPs into dental resins. The inclusion of either nonfunctionalized or functionalized $\mathrm{TiO}_{2}$ NPs within certain composite materials has been shown to enhance both the mechanical performance $[12,13]$ and the antibacterial potential [14-16] of dental resins. Dental adhesives are composed of resins or low-filler-content composites, [17-19] which function to bond dental resin composites to teeth. The strength and durability of dental adhesives are the key factors for ensuring a successful and durable dental restoration. Incorporation of functionalized $\mathrm{TiO}_{2} \mathrm{NPs}$ within dental adhesives may enhance the service life of dental restorations by promoting stronger bonding to human teeth $[10,11]$.

Due to the growing use of NPs in nanomedicines and in dental materials/devices, there is an increasing awareness that the potential clinical benefits of NPs must be balanced by a rigorous understanding and characterization of their potential safety risks [20-22]. It was previously shown that nonfunctionalized $\mathrm{TiO}_{2}$ NPs generated ROS with visible light irradiation (400 nm to $800 \mathrm{~nm}$ ) in a cellfree solution and that these ROS were capable of inducing statistically increased levels of DNA base damage (DNA lesions) in calf thymus DNA (ct-DNA) [23]. In that study, the authors provided strong evidence based on the pattern of DNA lesions quantified using gas chromatography/tandem mass 
spectrometry (GC/MS/MS) analysis that the DNA damage was likely generated from hydroxyl radical $\left({ }^{\circ} \mathrm{OH}\right)$ attack on the DNA. Other studies using mammalian cell-based models have also investigated both the potential cytotoxicity and genotoxicity induced by exposure to nonfunctionalized $\mathrm{TiO}_{2} \mathrm{NPs}$ [24-31]. In most instances, the potential genotoxicity determination was based on either the induction of DNA strand breaks using the comet assay and/or the formation of chromosome micronuclei using the micronucleus assay. In these studies, the NPs typically caused genotoxicity after irradiation, with results mainly attributable to $\mathrm{TiO}_{2}$ NP induced ROS and the subsequent increase in cellular oxidative stress [2431]. However, functionalized $\mathrm{TiO}_{2} \mathrm{NPs}$ which generate more and/or longer lasting ROS under light irradiation may pose different or increased risks.

In this study, we investigate if ROS generated by carboxylic acid-functionalized (acrylic or acetic acid) $\mathrm{TiO}_{2}$ NPs can be effectively and safely utilized to enhance the performance of dental adhesives. The $\mathrm{TiO}_{2}$ NPs were functionalized and then characterized using multiple analytical techniques. Fourier transform infrared (FTIR) spectroscopy was utilized to determine the identity of the attached functional groups. Thermal gravimetric analysis (TGA) was performed to assess the quantity (mass fraction) of functional group attachment to the NPs. And finally, electron paramagnetic resonance (EPR) was used to evaluate the photoactivities of the NPs in both dry powder form and in aqueous suspension. The capacity of the carboxylic acid-functionalized NPs to induce DNA damage upon visible light exposure was then quantitatively assessed. Focusing only on the acrylic acid-functionalized NPs, the performance of three NP-containing dental adhesives (compared to control resins without NPs) were assessed in terms of shear bond strength and morphological impact on material/tooth interfaces. Finally, two important issues regarding the amount of light exposure utilized during curing of dental adhesives and the possible leaching of NPs from cured nanocomposites are critically evaluated and discussed in order to address potential concerns regarding NP biocompatibility and genotoxicity. 


\section{Materials and Methods}

\subsection{Materials:}

Triethyleneglycol dimethacrylate (TEGDMA or T), 2-bis(4-(2-hydroxy-3-methacryloxypropoxy)-phenyl)-propane) (Bis-GMA or B), pyromellitic-glycerol-dimethacrylate (PMGDM or P) and hydroxyethyl-methacrylate (HEMA or H) were obtained from Esstech Inc (Essington, PA, USA). The initiators, camphorquinone (CQ) and ethyl 4-N, N-dimethylaminobenzoate (4E), acrylic acid, acetic acid, nitrilotriacetic acid disodium salt (NTA), iron chloride $\left(\mathrm{FeCl}_{3}\right), 30 \%$ (volume fraction) hydrogen peroxide $\left(\mathrm{H}_{2} \mathrm{O}_{2}\right)$, hydrochloric acid (99.99\% purity), calf thymus DNA-sodium salt (ct-DNA), sodium phosphate monobasic and sodium phosphate dibasic were purchased from Sigma-Aldrich Corp (St. Louis, MO, USA). NIST SRM 1898 ( $\mathrm{P} 25 \mathrm{TiO}_{2} \mathrm{NP}$ ) was obtained from the NIST Standard Reference Materials Program; the $\mathrm{TiO}_{2}$ NPs are composed of both anatase and rutile phases and were developed by Evonik Industries (Parsippany, NJ, USA). 4,6-Diamino-5-formamidopyrimidine- $-{ }^{13} \mathrm{C},{ }^{15} \mathrm{~N}_{2}$ (Fapy adenine${ }^{13} \mathrm{C},{ }^{15} \mathrm{~N}_{2}$ ), 2,6-diamino-4-hydroxy-5-formamidopyrimidine- $-{ }^{13} \mathrm{C},{ }^{15} \mathrm{~N}_{2} \quad$ (Fapy guanine- $-{ }^{13} \mathrm{C},{ }^{15} \mathrm{~N}_{2}$ ), $\quad$ 8hydroxyadenine- ${ }^{15} \mathrm{~N}_{5}\left(8-\mathrm{OH}\right.$-adenine- $\left.{ }^{13} \mathrm{C},{ }^{15} \mathrm{~N}_{2}\right)$, -hydroxy-5-methylhydantoin- ${ }^{13} \mathrm{C},{ }^{15} \mathrm{~N}_{2}$ (5-OH-5-MeHyd${ }^{13} \mathrm{C},{ }^{15} \mathrm{~N}_{2}$ ) and 8-hydroxy-2'-deoxyguanosine- ${ }^{15} \mathrm{~N}_{5}$ were purchased from Cambridge Isotope Laboratories (Andover, MA). 8-Hydroxyguanine- ${ }^{15} \mathrm{~N}_{5}\left(8-\mathrm{OH}\right.$-guanine- $\left.{ }^{15} \mathrm{~N}_{5}\right)$ was obtained by hydrolysis of 8-hydroxy$2^{\prime}$-deoxyguanosine- ${ }^{15} \mathrm{~N}_{5}$ with $60 \%$ formic acid at $140{ }^{\circ} \mathrm{C}$ for $30 \mathrm{~min}$ followed by lyophilization. Subsequently, 8-OH-guanine- $-{ }^{15} \mathrm{~N}_{5}$ was dissolved in $10 \mathrm{mmol} / \mathrm{L} \mathrm{NaOH}$ before use. E. coli formamidopyrimdine DNA glycosylase (Fpg) and E. coli endonuclease (III) (EndoIII) were purchased from Trevigen (Gaithersburg, MD). Chelex 100 resin was purchased from BioRad Laboratories (Hercules, CA). Plastic UV-transparent spectrophotometric cuvettes were purchased from Sigma (St. Louis, MO). Microcon Ultracel YM-30 centrifugal filters (30 kDa molecular weight cut-off) were obtained from Millipore (Billerica, MA). Distilled and deionized water $\left(\mathrm{ddH}_{2} \mathrm{O}\right)$, obtained from a Waters Milli-Q system, was used to prepare all aqueous solutions. All reagents were used as received. 


\subsection{Functionalization of $\mathrm{TiO}_{2} \mathrm{NPs}$.}

The P25 $\mathrm{TiO}_{2}$ NPs were functionalized with acrylic acid (AP25) and/or acetic acid (AceP25) following a modified version of a previously published method [11, 32]. AP25 NPs were prepared according to the following procedure: acrylic acid (7.2 g), water $(0.8 \mathrm{~g})$, hexane $(8 \mathrm{~g})$ and P25 (0.2 g) were combined and sonicated at $0{ }^{\circ} \mathrm{C}$ for 30 min using a $130 \mathrm{~W}$ ultrasonic processor (model\# GEX 130PB, Cole-Parmer, USA). The mixture was then agitated at $52.4 \mathrm{rad} / \mathrm{sec}$ at $37^{\circ} \mathrm{C}$ for $48 \mathrm{~h}$. The resulting milky mixture was transferred into a $50 \mathrm{~mL}$ centrifuge tube and centrifuged (Beckman J2-21, Rotor adaptor JA20, Indianapolis, IN, USA) at $19000 \mathrm{~g}$ (13000 rpm) for $60 \mathrm{~min}$. The AP25 precipitate was collected and redistributed in $25 \mathrm{~mL}$ of ethanol, which was centrifuged again at $19000 \mathrm{~g}(13000 \mathrm{rpm})$ for $60 \mathrm{~min}$. The redistribution and centrifugation steps were repeated two more times to remove the excess acrylic acid loosely adsorbed on the surface of the AP25 NPs. The NPs were then dried under vacuum. An identical protocol was used to prepare AceP25 NPs.

\subsection{Characterization of functionalized $\mathrm{TiO}_{2} \mathrm{NPs}$.}

The $\mathrm{TiO}_{2}$ NPs were characterized using FTIR, TGA, dynamic light scattering (DLS) and EPR. FTIR spectroscopic measurements were performed on a Nexus 670 FTIR spectrophotometer (Thermo Scientific, Madison, WI, USA). NPs were mixed with KBr powder (1.5 mg AP25 or AceP25 and $150 \mathrm{mg}$ $\mathrm{KBr}$ ) and pressed into pellets, which were examined in transmission mode. A total of 64 scans were collected from $4000 \mathrm{~cm}^{-1}$ to $650 \mathrm{~cm}^{-1}$ at a $4 \mathrm{~cm}^{-1}$ resolution. All measurements were performed in triplicate $(\mathrm{n}=3)$. TGA was performed using a TGA Q500 (TA Instruments). Samples $(\approx 10 \mathrm{mg})$ were placed on a platinum weighing pan and heated from room temperature to $115^{\circ} \mathrm{C}$ at a rate of $10{ }^{\circ} \mathrm{C} / \mathrm{min}$, kept at $115^{\circ} \mathrm{C}$ for $60 \mathrm{~min}$, and then heated to $600{ }^{\circ} \mathrm{C}$ at a rate of $10^{\circ} \mathrm{C} / \mathrm{min}$. The entire process was conducted under flowing $\mathrm{N}_{2}$. Stock suspensions $(1000 \mathrm{mg} / \mathrm{L})$ in $5 \mathrm{mmol} / \mathrm{L}$ phosphate buffer $(\mathrm{pH} 7.4)$ were prepared using a standardized sonication method described previously [33]. The NP size distribution was assessed using DLS (after probe sonication to produce a dispersion) on a Brookhaven instrument (90PLUS/BI-MAS mode, Brookhaven Instruments Cooperation, New York, USA) at a 90degree angle in ethanol $\left(25^{\circ} \mathrm{C}\right)$. A $15 \mathrm{~mW}$ solid state laser with a wavelength of $532 \mathrm{~nm}$ was used. The 
hydrodynamic radius $\left(R_{\mathrm{h}}\right)$ of the NPs and their size distributions were calculated employing the Brookhaven Instruments-provided software [34, 35]. All measurements were repeated three times $(n=3)$.

EPR measurements were performed using an x-band square cavity (TE011 mode), microwave frequency $\approx 9.38 \mathrm{GHz}$, field modulation $=100 \mathrm{kHz}$, and microwave power $=10 \mathrm{~mW}($ BRUKER BioSpin ElexSys500 spectrometer, Billerica, MA, USA). Each specimen was placed in a capped quartz EPR tube ( $0.4 \mathrm{~mm}$ thin wall tube, $20 \mathrm{~cm}$ long) in the EPR cavity. All spectra were obtained at $77 \mathrm{~K}$ by sweeping the static magnetic field and recording the first derivative of the absorption spectrum. Unexposed specimens and empty EPR tubes were tested for reference spectra. A weak pitch standard sample was measured under identical instrumental conditions periodically to correlate the position of EPR signals, and double integrals of EPR spectra were analyzed to determine the intensity of peaks. Both $\mathrm{TiO}_{2} \mathrm{NP}$ powders and suspensions were evaluated. The powder was measured directly in the EPR tube, and the $\mathrm{NP}$ suspensions (1000 mg/L) were mixed with 3-amino-2, 2, 5, 5-tetramethyl-1-pyrrolidinyloxy (3AP) spin-trap solution $(100 \mu \mathrm{mol} / \mathrm{L})$. The concentration of $3 \mathrm{AP}$, as well as EPR instrument parameters, were optimized to obtain the appropriate signal intensity and sensitivity for the NP incubation systems. The incubation/spin trap systems were measured for $30 \mathrm{~min}$ to ensure equilibrium. In addition, in-situ visible light EPR experiments via irradiation of the cavity were performed after the 30 min measurements of the incubation/spin trap system to assess NPs photo-reactivity. Visible light irradiation was provided by a $500 \mathrm{~W}$ Xe arc lamp with a $420 \mathrm{~nm}$ to $630 \mathrm{~nm}$ dichroic mirror. The light intensity at the samples was 25 $\mathrm{mW} / \mathrm{cm}^{2}$. (experiments were performed in duplicate; $\mathrm{n}=2$ ).

\subsection{DNA damage studies of AP25 and AceP25 using dark and visible light conditions.}

Calf thymus DNA stock solutions $(500 \mathrm{mg} / \mathrm{L})$ were prepared by dissolving the appropriate amount of ct-DNA in $\mathrm{ddH}_{2} \mathrm{O}$. Transition metals and other impurities were removed by treating the ctDNA solutions with Chelex resin combined with extensive dialysis (3500 Da MWCO membranes) against $\mathrm{ddH}_{2} \mathrm{O}$ at $4{ }^{\circ} \mathrm{C}$ [36]. Calf thymus DNA stock solutions were stored at $4{ }^{\circ} \mathrm{C}$ until needed. The positive controls were ct-DNA samples chemically damaged with NTA, $\mathrm{FeCl}_{3}$ and $\mathrm{H}_{2} \mathrm{O}_{2}$ as previously 
described [36]. The positive control ct-DNA samples were prepared in $100 \mu \mathrm{g}$ aliquots, dried under vacuum using a Speed Vac, and stored at $4{ }^{\circ} \mathrm{C}$ until needed. Positive controls were resolubilized with $\mathrm{ddH}_{2} \mathrm{O}$ (gentle shaking at $4{ }^{\circ} \mathrm{C}$ for $24 \mathrm{~h}$ ) and run with every set of samples to verify sample preparation procedures and instrument performance.

For the dark exposure study, a $250 \mathrm{mg} / \mathrm{L}$ AP25 suspension was prepared by volumetrically diluting the $1000 \mathrm{mg} / \mathrm{L}$ AP25 stock suspension with $\mathrm{ddH}_{2} \mathrm{O}$. A $100 \mathrm{mmol} / \mathrm{L}$ phosphate buffer solution ( $\mathrm{pH}$ 7.4) was prepared by appropriately combining monobasic and dibasic phosphate salts in $\mathrm{ddH}_{2} \mathrm{O}$. After utilizing Chelex resin to remove transition metal impurities, the $\mathrm{pH}$ of the phosphate buffer was adjusted using $\mathrm{HCl}$. In a darkened laboratory with no exterior sunlight, appropriate volumes of the 100 mmol/L phosphate buffer solution, the $500 \mathrm{mg} / \mathrm{L}$ ct-DNA stock solution and the $250 \mathrm{mg} / \mathrm{L}$ AP25 solution were added into UV opaque amber 2 -mL microfuge vials to make $1 \mathrm{~mL}$ samples containing $5 \mathrm{mmol} / \mathrm{L}$ phosphate buffer, $250 \mu \mathrm{g}$ ct-DNA and increasing AP25 concentrations $(0.5 \mathrm{mg} / \mathrm{L}, 5 \mathrm{mg} / \mathrm{L}, 50 \mathrm{mg} / \mathrm{L})$. Six samples were prepared per condition and all of the samples including the negative controls were incubated in the dark at $37^{\circ} \mathrm{C}$ on a rotating $(100 \mathrm{rpm} ; 10.5 \mathrm{rad} / \mathrm{s})$ shaker $(\mathrm{C} 24$ Incubator Shaker) for $24 \mathrm{~h}$. Two types of negative control samples were utilized during the study: 1) an acid ligand control (4 mg/L final concentration of acrylic acid) control was used to investigate the effect of the acid ligand, if any, on the induction of DNA damage, and 2) a ct-DNA control was used to determine the background lesion level in the DNA samples. Following the dark exposure period, the DNA was quantitatively isolated from the samples, amended with the five stable isotopically labeled DNA lesion analogues and prepared for GC/MS/MS analysis [37]. All samples were enzymatically digested and analyzed via GC/MS/MS methodology based upon procedures described in previous studies [23, 37-39]. Full details of the methodology are available in the Supporting Information (SI).

For the visible light exposure study, experimental samples were prepared identically to the samples in the dark exposure study, except that precautions were not taken to limit laboratory light during sample preparation and the samples were initially prepared using plastic disposable UV transparent 
cuvettes. Samples and negative controls were exposed to visible light radiation (400 $\mathrm{nm}$ to $800 \mathrm{~nm}$;

Figure S1 shows the spectral intensity of the light source from $300 \mathrm{~nm}$ to $800 \mathrm{~nm}$ for completeness) for $24 \mathrm{~h}$ at $37^{\circ} \mathrm{C}$. The experimental setup and calibration of the fluorescent light utilized to generate the visible light radiation were described previously [37]. The total irradiance on the samples was 1600 $\mathrm{mW} / \mathrm{cm}^{2}$. Following the visible light exposure period, the DNA was isolated, amended with the labeled DNA lesion analogues and prepared for GC/MS/MS analysis using the method described for the dark exposure condition. For the AceP25 NPs, the dark and visible light exposure study and the GC/MS/MS DNA damage analyses were performed as described above for AP25 except that acetic acid was used as the acid ligand control.

\subsection{AP25 nanocomposites: formulation, polymerization and degree of vinyl conversion (DC).}

Three distinct monomer mixtures, i.e., Bis-GMA-HEMA (B/H, 1/1 by mass), Bis-GMATEGDMA (B/T, 1/1 by mass), and PMGDM-HEMA (P/H, 1/1 by mass) were used to formulate the resins. The photo-initiator system was comprised of $0.2 \%$ w/w CQ and $0.8 \%$ w/w 4E. AP25 was dispersed in anhydrous ethanol through sonication. Appropriate amounts of the NPs suspension were combined with monomer mixtures, and ethanol was evaporated by bubbling dry air ( $15 \mathrm{~mL} / \mathrm{min}$ for $24 \mathrm{~h})$. The resulting AP25 nanocomposites containing $1 \mathrm{~g} / \mathrm{L}(0.1 \%$ by mass and $0.024 \%$ by volume $)$ AP2 25 were then pipetted into a plastic mold (6 $\mathrm{mm}$ in diameter and $1.5 \mathrm{~mm}$ in thickness) and sandwiched by Mylar film to prevent oxygen inhibition. The tubes were irradiated with a Triad 2000 visible light curing unit (Dentsply, York, PA, USA) with a tungsten halogen light bulb $\left(75 \mathrm{~W}\right.$ and $\left.120 \mathrm{~V}, 43 \mathrm{~mW} / \mathrm{cm}^{2}\right)$ for $2 \mathrm{~min}$ each, from both the top and bottom sides of the assembly, and for two min per side. The DC of resin and composite specimens was determined using near infrared spectroscopy (NIR) [40-42]. NIR spectra were acquired before photo cure and at $24 \mathrm{~h}$ post cure. DC $(\mathrm{n}=3)$ was calculated as the percentage change in the integrated peak area between the polymer (value after cure) and monomer (values before cure) of the $6,165 \mathrm{~cm}^{-1}$ vinyl absorption band normalized to the $4,623 \mathrm{~cm}^{-1}$ aromatic $\mathrm{C}-\mathrm{H}$ absorption band. 


\subsection{AP25 nanocomposites: characterization by transmission electron microscopy (TEM) and energy dispersive spectroscopy (EDS).}

The composites were sectioned using an ultramicrotome (PT-XL PowerTome, RMC Products, Tucson, AZ, USA), and the AP25 in the composites were characterized by TEM and EDS. A glass knife, prepared from glass strips (400 mm x $25 \mathrm{~mm}$ x $6.4 \mathrm{~mm}, 8032$, Ted Pella Inc., Redding, CA, USA) using a knifemaker (Type 705202 KnifeMaker, Reichert-Jung Leica Microtome, Lorton, VA, USA), was used to trim the composites resin (resin $\mathrm{B} / \mathrm{T}=1 / 1$ by mass, containing $1000 \mathrm{mg} / \mathrm{L}$ of AP25) block. Ultrathin ( 100 $\mathrm{nm}$ thick) sections were cut from the trimmed resin block using a diamond knife (122-MT-30, Ted Pella Inc.). The cut sections were then collected onto a 300 mesh Cu TEM grid (12571-CU, Ted Pella Inc.). TEM images were taken on an analytical TEM (Titan 80-300, FEI Company, Hillsboro, OR, USA) operating at $300 \mathrm{kV}$ in bright-field mode. EDS spectra were acquired from the imaged areas using an $\mathrm{Si}$ (Li) X-ray energy-dispersive spectrometer (EDAX Inc., Mahwah, NJ, USA), with an acquisition time of $120 \mathrm{~s}$.

\subsection{Real-time DC}

Real-time in situ monitoring of the visible-light-induced photopolymerization of resin adhesives or nanocomposites was performed using FTIR (Spectrum 400 FTIR spectrophotometer, Perkin-Elmer, Waltham, MA, USA) at a spectral resolution of $4 \mathrm{~cm}^{-1}[18,43-46]$. One drop of adhesive solution was placed on the diamond crystal top-plate of an attenuated total reflectance (ATR) accessory (Pike, GladiATR, Pike Technology, Madison, WI, USA) and covered with a mylar film. A $40 \mathrm{~s}$ exposure to a commercial visible-light-polymerization unit (Spectrum $800^{\circledR}$, Dentsply, Milford, DE, USA; [43]) at an intensity of $550 \mathrm{~mW} / \mathrm{cm}^{2}$ was initiated after 50 FTIR spectra had been recorded. Real-time IR spectra were recorded continuously for $600 \mathrm{~s}$ after light curing began. A time-resolved spectrum collector (Spectrum TimeBase, Perkin-Elmer, Waltham, MA, USA) was used for continuous and automatic collection of spectra during polymerization. 
DC was determined as the ratio $\left(1637 \mathrm{~cm}^{-1}(\mathrm{C}=\mathrm{C}) / 1715 \mathrm{~cm}^{-1}(\mathrm{C}=\mathrm{O})\right)$ of un-polymerized and polymerized specimens according to the following equation:

$$
\operatorname{DC}(\%)=\left[\left(\mathrm{A}_{1} / \mathrm{A}_{0}-\mathrm{A}_{1}^{\prime} / \mathrm{A}_{0}{ }^{\prime}\right) /\left(\mathrm{A}_{1} / \mathrm{A}_{0}\right)\right] \cdot 100
$$

where $\mathrm{A}_{1} / \mathrm{A}_{0}$ and $\mathrm{A}_{1}{ }^{\prime} / \mathrm{A}_{0}{ }^{\prime}$ correspond to the peak area-ratio of the vinyl-of-interest $\left(\mathrm{A}_{1}\right.$ : before polymerization, and $\mathrm{A}_{1}$ : after polymerization) and the internal standard $\left(\mathrm{A}_{0}\right.$ and $\left.\mathrm{A}_{0}\right)$, respectively. The DC value at $10 \mathrm{~min}$ is calculated as the average of the last 50 time-based data points.

\subsection{Shear bond strength (SBS).}

Human teeth used in SBS testing were obtained according to the protocols approved by the American Dental Association (ADA)'s Institutional Review Board. The teeth were sterilized with sodium azide and stored in deionized water at $4{ }^{\circ} \mathrm{C}$ until use. The SBS test followed a previously established protocol in our center $[47,48]$. Briefly, teeth were embedded with Fastray composite (Harry J. Bosworth Company, Skokie, IL, USA) in cylindrical holders and ground perpendicular to their long axis with 320grit $\mathrm{SiC}$ paper until the occlusal enamel was completely removed. A three-step adhesive procedure was employed (\% concentrations represent a mass fraction). First, the dentin surface was etched with a $37 \%$ phosphoric acid gel (Etch-Rite; Pulpdent Corp., Watertown, MA, USA) for $15 \mathrm{~s}$ and then rinsed with distilled water. After rinsing, the dentin surface was hydrated with moist blotting paper. The next step involved the application of a mixture of $20 \mu \mathrm{L} 5 \% \mathrm{Mg}$-(N-tolylglycine glycidyl methacrylate $)_{2}$ acetone solution and $40 \mu \mathrm{L}$ of $20 \%$ PMGDM acetone solution that contained $2 \%$ benzoyl peroxide (mass fraction based on resin). This solution was applied as a primer to the dentin surface; the solution was brushed onto the surface 5 independent times (the solvent was evaporated by air drying between applications) so that at the end of the $5^{\text {th }}$ application, five layers of primer were adhered to the dentin surface. Finally, the resins and/or the corresponding AP25 composites were applied as bonding agents and were brushed once on the coated dentin surface. The entire dentin surface was then light cured for $40 \mathrm{~s}$ (8 mm tip on a quartz halogen light source; output of $450 \mathrm{~mW} / \mathrm{cm}^{2}$ (Max 100, Caulk/Dentsply, Milford, DE, USA)). A poly(tetrafluoroethylene)-covered stainless steel ring (opening diameter $4 \mathrm{~mm}$; 
thickness $1.5 \mathrm{~mm}$ ) defined the bonding area through which the composite was applied onto the coated dentin. The ring was held down by a polycarbonate holder and the iris was filled with TPH Spectra ${ }^{\mathrm{TM}}$ composite (Caulk/Dentsply, Milford, DE, USA). The assembly was then irradiated for $1 \mathrm{~min}$ (same light source), and $5 \mathrm{~min}$ after light irradiation, the assembly was placed in distilled water and stored for $24 \mathrm{~h}$ at approximately $22{ }^{\circ} \mathrm{C}$ before conducting the SBS test. Commercially available bonding solution (Scotchbond, 3M ESPE, St. Paul, MN, USA) was used as a control. The experimental materials were comprised of three resins and the corresponding AP25 composites. De-bonding was performed as follows: the brass ring holding the dentin-bonded material was placed against a vertical surface of a nylon block. The ring and the composite were sheared off, at a crosshead speed of $0.5 \mathrm{~mm} / \mathrm{min}$, with a flat chisel pressing against the edge of the steel iris. The flat chisel was connected to the platen of a Universal Testing Machine (Instron 5500R, Instron Corp., Canton, MA, USA). The maximum de-bonding load was converted into the SBS of the specimen. The mean values of SBS were the average of five measurements for each adhesive $(n=5)$.

\subsection{Tooth/adhesive interphase: morphology of a hybrid layer}

Teeth, selected and sterilized as described in the SBS section, were embedded onto cubic holders and ground perpendicular to their long axis with 320-grit sand paper until the occlusal enamel was completely removed. The freshly ground tooth surface was divided into two parts. The first two steps (of a three-step adhesive procedure) were performed on both halves of the tooth. Then, as a third step, adhesive resins without NPs were applied to one half of the tooth and the corresponding AP25 composites ( $0.1 \%$ mass fraction) to the other of the tooth. To prevent mixing of the two adhesives, two halves of each specimen were separated by a cover glass. The cover glass was removed, and a layer of TPH (approximately $1 \mathrm{~mm}$ thick) was cured on top of the adhesive layers. The teeth were then sectioned into $0.4 \mathrm{~mm}$ thick slices perpendicular to the dividing line. These slices were divided into two groups: one was treated with $37 \%$ phosphoric acid for $15 \mathrm{~s}$ and then bleach (Clorox ${ }^{\circledR}$, Oakland, CA, USA) for $7 \mathrm{~min}$. Specimens from the other group were first polished with wet silicon carbide paper (600-, 1200-, 2400-, and 4000-grit size; in succession) and then argon-etched to disclose the interfacial structure. The 
specimens were then dehydrated by being subsequently immersed for $10 \mathrm{~min}$ in ethanol solutions of ascending concentrations: $25 \%, 35 \%, 45 \%, 55 \%, 65 \%, 75 \%, 85 \%, 95 \%$ and $100 \%$ and then polished with special soft discs with diamond suspensions (Liquimant, Vos \& Van Eyck Metallurgie, Vianen, The Netherlands) of, successively, 3- and 1- $\mu \mathrm{m}$ particle size in combination with lubricant cooling solution (DPLubricant Blue cooling solution, Struers, Copenhagen, Denmark). Polishing entailed successive treatments with 3 - and $1-\mu \mathrm{m}$ particle size suspensions combined with a lubricant cooling solution (DPLubricant Blue cooling solution, Struers, Copenhagen, Denmark). The polished samples were air-dried overnight before being argon-etched for $2 \min [49,50]$. The etched specimens were then mounted on aluminum stubs and gold-sputtered, and their morphology examined by SEM (10 kV; JSM5300, JEOL, Waterford, VA, USA).

\subsection{Thermal cycling and leachate analysis}

The composite bars $\left(2 \times 2 \times 25 \mathrm{~mm}^{3}\right)$ were immersed in $1 \mathrm{~mL}$ of $0.15 \mathrm{~mol} / \mathrm{L}$ sodium chloride solution $24 \mathrm{~h}$ after curing, and subjected to 2500 thermal cycles (Thermocycling Test Apparatus, Sabri Dental Enterprises, IL, USA) between $5{ }^{\circ} \mathrm{C}(85 \mathrm{~s})$ and $55^{\circ} \mathrm{C}(45 \mathrm{~s})$. The titanium contents in the leachate were evaluated using inductively coupled plasma-optical emission spectroscopy (ICP-OES, Prodigy High Dispersion ICP, Teledyne Leeman Labs, Hudson, NH, USA) calibrated with a series of standard Tisolutions (Sigma-Aldrich Corp, St. Louis, MO, USA). All samples were digested in nitric acid (trace metal grade, Fisher Scientific, USA) prior to ICP analysis following previously published procedures [51]. Briefly, the solutions $(0.5 \mathrm{~mL})$ collected after 2500 thermal cycles were mixed with $0.5 \mathrm{~mL}$ of $40 \%$ w/w $\mathrm{HNO}_{3}$ and allowed to digest at room temperature for $24 \mathrm{~h}$ with shaking $(500 \mathrm{rpm})$. Each sample was measured three times $(n=3)$.

\subsection{Statistical analysis}

Graphpad Prism 6.0 software (La Jolla, CA, USA) was utilized for statistical analyses. For the DC data, significant differences between control resins and resins amended with AP25 were determined by the Student's t-test (two-tailed, unpaired data). For the DNA damage data, significant differences among the measured DNA lesion levels were determined by one-way Analysis of Variance (ANOVA) with post 
hoc Dunnett's multiple comparison test $(\alpha=0.05)$ between the control samples and the experimental samples. The final data was log transformed before statistical significance testing because homogeneity of variance (Bartlett's test) was not satisfied for the non-transformed data.

\section{Results and Discussion}

\subsection{Characterization of functionalized NPs.}

Successful functionalization of the $\mathrm{TiO}_{2}$ NPs was confirmed by FTIR and TGA. The FTIR spectra (Figure 1A) of non-functionalized P25, AP25 and AceP25 exhibited a peak at $1630 \mathrm{~cm}^{-1}$, corresponding to $\mathrm{H}-\mathrm{O}$ bending. The spectra of AP25 and AceP25 also showed the asymmetric $\left(v_{a s}\right)$ and symmetric $\left(v_{s}\right)$ stretching vibrations from the $\mathrm{COO}^{-}$groups at $1539 \mathrm{~cm}^{-1}$ and $\sim 1430 \mathrm{~cm}^{-1}$, respectively. The wave-number differences between $v_{a s}\left(\mathrm{COO}^{-}\right)$and $v_{s}\left(\mathrm{COO}^{-}\right)$were $102 \mathrm{~cm}^{-1}$ and $116 \mathrm{~cm}^{-1}$ for AP25 and AceP25, respectively. These differences are attributable to the chelating bidentates between acrylic acid and the $\mathrm{TiO}_{2}$ surface. In addition, the $-\mathrm{C}=\mathrm{C}-$ stretching at $1636 \mathrm{~cm}^{-1}$ was observed in the AP25 spectrum. The TGA results (Figure 1B) showed a mass loss of $1.64 \% \pm 0.01 \%$ and $1.61 \% \pm 0.03 \%$ for AP25 and AceP25, respectively, in the $115{ }^{\circ} \mathrm{C}$ to $600{ }^{\circ} \mathrm{C}$ temperature region. After subtracting the P25 mass loss $(0.79 \% \pm 0.10 \%)$ in the same temperature range, the weight loss of the functionalized NPs was approximately $1 \%$. The derivative of weight loss as a function of temperature (Figure 1C) indicated that the functional groups on AP25 (one peak at $396{ }^{\circ} \mathrm{C}$ ) bifurcate at a higher temperature than those on AceP25 (two peaks at $306{ }^{\circ} \mathrm{C}$ and $350{ }^{\circ} \mathrm{C}$ ). This phenomenon suggested a relatively stronger chelation to $\mathrm{TiO}_{2}$ in AP25, which agreed with the FTIR results.

\subsection{Photoactivity of functionalized NPs.}

The capacity of the functionalized NPs powders and suspensions to generate ROS under visible light irradiation was evaluated by direct EPR or EPR spectroscopy in combination with the spin trapping agent (3AP), respectively. The relative ROS intensity as a function of light irradiation time (Figure $\mathbf{2 A}$ ) typically increased rapidly at first and then plateaued. The nonfunctionalized $\mathrm{TiO}_{2} \mathrm{NPs}(\mathrm{P} 25)$ reached a constant ROS intensity much faster than the functionalized NPs (AP25 and AceP25), probably due to 
recombination of the generated electrons and holes [10]. In the AP25 or AceP25 systems, functional groups on the surface of the NPs apparently slowed down the electron/hole recombination. Consequently, higher levels of ROS were detected during the analyses of AP25 and AceP25. The EPR spectra of the NPs after $1 \mathrm{~h}$ of visible light irradiation (Figure 2B) further demonstrated the ROS enhancing effects of the NP functional groups.

ROS production in aqueous NP suspensions was evaluated using three concentrations of nonfunctionalized $\mathrm{TiO}_{2}$ NPs (Figure 2C), $0 \mathrm{mg} / \mathrm{L}, 50 \mathrm{mg} / \mathrm{L}$ and $1000 \mathrm{mg} / \mathrm{L}$, in the presence of a constant concentration of 3AP. The EPR signal decrease for 3AP was proportional to the increase in ROS production. Under light irradiation, the higher concentrations of $\mathrm{TiO}_{2} \mathrm{NPs}$ generated more ROS. The EPR signal dropped to $80.0 \% \pm 2.3 \%$ after $30 \mathrm{~min}$ of light exposure when $50 \mathrm{mg} / \mathrm{L}$ of $\mathrm{TiO}_{2} \mathrm{NPs}$ was added. It required only $180 \mathrm{~s}$ for the signal to drop to $80 \%$ with light exposure at a NP concentration of 1000 mg/L. Furthermore, nonfunctionalized $\mathrm{TiO}_{2}$ NPs did not generate any detectable radicals when there was no light exposure.

Functionalization of the $\mathrm{TiO}_{2}$ NPs improved ROS production in aqueous suspensions (Figure 2D). At the start of the light irradiation, the 3AP EPR signal decreased linearly and attained a constant value within approximately $900 \mathrm{~s}$ of irradiation. Presumably, the plateau values correspond to the maximum ROS level that can be generated under the given experimental conditions, i.e., at a NP concentration of $1000 \mathrm{mg} / \mathrm{L}$. In order to determine the rate of ROS production, the NP EPR signals were fitted to a linear equation for a time period up to $750 \mathrm{~s}$ and arithmetically averaged for time periods > $1000 \mathrm{~s}$. The results are summarized in Table 1. The rate of ROS production by visible-light (measured by the value of the linear slope) showed the following trend: AceP25 > AP25 > P25. The average ROS production by UV-light followed the same trend but the rate of ROS production was faster (Figure S2).

\subsection{Genotoxic potential of functionalized NPs.}

In order to assess the genotoxic potential of the functionalized NPs, solutions of ct-DNA were incubated with increasing NP concentrations under controlled laboratory conditions in the dark or under visible light irradiation as recently described [23]. The resulting DNA base damage was measured using 
high resolution GC/MS/MS analyses. DNA damage profiles for ct-DNA exposed to AP25 under dark conditions are shown in Figure 3A. There was no statistically significant formation of oxidatively induced DNA base damage detected in any of the samples in comparison to either the negative control samples or the acrylic acid ligand control samples. Conversely, significant levels of increased DNA damage were detected (for 4 out the 5 monitored lesions) at the highest AP25 exposure concentration (50 mg/L AP25) when the samples were exposed to visible light irradiation (Figures 3B). Similar results were obtained for ct-DNA samples exposed to AceP25 in the dark and under visible light irradiation solution conditions (Figure 4). DNA damage profiles showing the response from positive controls for AP25 (Figure S3) and AceP25 (Figure S4) are provided in the Supporting Information. Overall, these data indicate that highly concentrated AP25 or AceP25 in solution have the potential to induce DNA damage when the NPs are photoactivated. This laboratory finding demonstrates that these functionalized NPs have the capacity to generate ROS that can oxidatively modify bases within double stranded DNA. It is unlikely that the required mass concentration of AP25 or AceP25 needed to induce DNA damage can leach from resin composites or resin dental adhesives (see below) that contain these NPs. However, studies in cell-based models are warranted in order to further characterize the genotoxic potential of these novel dental resin components.

\subsection{Characterization of AP25 in dental resin}

TEM imaging of an ultrathin section of dental resin containing $1000 \mathrm{mg} / \mathrm{L}$ AP25 NPs showed clustered particles randomly scattered throughout the resin (Figure 5A, S5 and S6). While the average diameter of the individual AP25 particles $(\mathrm{n}=50)$ was $(26.6 \pm 9.6) \mathrm{nm}$, the average size of the AP25 agglomerates $(\mathrm{n}=10)$ was $(234 \pm 87) \mathrm{nm}$ along the long axis. Both values corresponded well with the previously reported data [18]. EDS analysis confirmed the presence of elemental titanium in the resin (Figure 5B). Lattice fringe image analysis of a single AP25 particle results in an average $d$-spacing of $0.355 \mathrm{~nm}$, consistent with the (101) plane of the anatase form of $\mathrm{TiO}_{2}$ (Figures 5C and 5D). On the basis of this data, it was concluded that the AP25 particles were firmly incorporated into the dental resin. 
In addition, the $\mathrm{DC}$ values for three different dental resin mixtures $(\mathrm{B} / \mathrm{T}, \mathrm{B} / \mathrm{H}$ and $\mathrm{P} / \mathrm{H})$ and their corresponding nanocomposites containing 1 g/L AP25 were determined and are shown in Figure 6. All of the nanocomposites showed small, but significantly higher DC values than the dental resin mixtures. These results agree well with recent literature reports indicating that NP addition to resins significantly increase DC values $[10,11]$.

\subsection{Development of stronger dental adhesives through incorporation of AP25}

Kinetic studies of the resins with or without AP25 were conducted to ascertain the proper photopolymerization conditions for dental adhesives. $\mathrm{B} / \mathrm{H}$ resin and its nanocomposites were analyzed as examples. DC is conventionally used to indicate the overall performance of the photo-polymerization by indicating a portion of monomers that have converted into polymers. Increased crosslinking is a typical result of increased DC in these dimethacrylate resins, which would presumably result in a stronger material. Real time DC values attained in light-irradiated $\left(550 \mathrm{~mW} / \mathrm{cm}^{2}\right) \mathrm{B} / \mathrm{H}$ resins and AP25 nanocomposites with two different levels of NPs and DC changes with time are presented in Figures S7A and S7B, respectively. In all specimens, almost $95 \%$ of the maximum monomer conversion occurred during the $40 \mathrm{~s}$ curing period. Nanocomposites containing $1000 \mathrm{mg} / \mathrm{L}$ of AP25 attained the highest DC. A five-fold increase in AP25 content $(5000 \mathrm{mg} / \mathrm{L})$ did not necessarily increase the DC values of the composites, but in fact, resulted in a reduction in DC values. The reduced vinyl conversion at higher NP concentrations may be attributed to the increased blocking of the light due to the high refractive index of $\mathrm{TiO}_{2}$, and their enhanced agglomeration. Significantly, it has been reported that in a series of AP25 nanocomposites with NP content between $200 \mathrm{mg} / \mathrm{L}$ and $5000 \mathrm{mg} / \mathrm{L}$, composites with $1000 \mathrm{mg} / \mathrm{L} \mathrm{NPs}$ exhibited the highest SBS values [11]. Based on the results of the present kinetic study and the previous literature data, $1000 \mathrm{mg} / \mathrm{L}$ AP25 nanocomposites were used in the remaining evaluations described in this article. Deviations from this AP25 concentration in some of the forthcoming experiments are specifically addressed.

Figure S7B illustrates the effects of light irradiation time on the DC obtained for the B/H AP25 nanocomposites. The nanocomposites were irradiated for $10 \mathrm{~s}, 20 \mathrm{~s}$ or $40 \mathrm{~s}$. While the nanocomposite 
irradiated for $20 \mathrm{~s}$ or $40 \mathrm{~s}$ reached DCs of approximately $60 \%$, their counterparts cured for $10 \mathrm{~s}$ reached DCs of only $40 \%$. Consequently, to ensure the highest consistency of the results, a $40 \mathrm{~s}$ irradiation time was used in SBS testing.

To determine whether the experimental nanocomposites indeed make stronger dental adhesives than their resin counterparts, the mechanical performance of $\mathrm{B} / \mathrm{T}(1 / 1), \mathrm{B} / \mathrm{H}(1 / 1)$ and $\mathrm{P} / \mathrm{H}(1 / 1)$ resins and their AP25 nanocomposites was evaluated. These particular resins have been previously used as dental adhesives $[11,17,19,52,53]$. Incorporation of $1000 \mathrm{mg} / \mathrm{L}$ of AP25 into these resins increased the average SBS values by $25.6 \%, 37.3 \%$ and $26.5 \%$ for the $\mathrm{B} / \mathrm{T}, \mathrm{B} / \mathrm{H}$ and $\mathrm{P} / \mathrm{H}$ formulations, respectively. Irrespective of the resin type, the overall average improvement in SBS achieved by introducing AP25 NPs was $28.7 \%$ ( $\mathrm{P}<0.05)$ (Figure 7). In addition, the observed SBS of AP25-containing adhesives was greater than that of the control resin (Scotchbond) $(\mathrm{P}<0.05)$. However, it is important to note that the enhanced initial SBS of the nanocomposites need to be maintained during the service life of the product under conditions of longterm aging and wear. Additional research is needed to investigate the enhanced SBS of the nanocomposites throughout their expected life cycle.

The hybrid layer thickness is also a metric commonly used to evaluate the performance of dental adhesives [11, 17, 19, 52, 53]. Based on the average hybrid layer thickness (Figure S8, determined by using a ruler to measure the number of pixels in SEM images) there was no detectable or statistical difference between the resins and the nanocomposites. Once surface dentin layer was removed, the resins/nanocomposites that actually penetrated into the dentin tubules were revealed (Figure 8). Visually, the nanocomposite had a rougher structure than the pure resin. It is generally accepted that bonding of dental adhesive to a tooth is an adsorption process rather than a strong covalent bond formation. Therefore, a rougher surface may lead to increased entanglement between the resin and dentin, leading to more friction between the two components, which results in an overall improvement the bond strength. In addition, light irradiation may make nanocomposites more hydrophilic $[10,52,53]$ which may enhance their interactions with teeth and result in a stronger bond. The two most important factors contributing to 
the increased mechanical strength of dental adhesives that contain functionalized $\mathrm{TiO}_{2} \mathrm{NPs}$ are the significantly increased DC values and the better integration of the resin nanocomposites with the dentin.

Due to the possible adsorption of the DNA base lesions onto the nanocomposite resins, determination of the potential DNA damage profiles directly on nanocomposites was not practical. However, in order to evaluate the potential genotoxicity and support the biocompatibility of AP25 as it is actually utilized and incorporated within the resin matrix, two additional experiments were performed: 1) a test to determine the maximum amount of AP25 that could leach from the nanocomposites and 2) a determination of the maximum ROS generation that could occur during the process of curing the dental adhesive. Although the optimal concentration $(1000 \mathrm{mg} / \mathrm{L})$ of AP25 in the prepared nanocomposites was 20 times higher than the effective dose $(50 \mathrm{mg} / \mathrm{L})$ that induced DNA damage when the AP25 was in aqueous suspension, the majority of the entangled NPs in the resin do not directly interact with DNA. However, it is important to know how many NPs may be released from the nanocomposites under realistic exposure conditions. In addition to potential genotoxic effects, the distribution of released NPs including potential translocation and accumulation in tissues, such as the kidney and liver are important concerns. A thermal cycling method combined with ICP-OES was used to quantitatively measure the leaching of AP25 from nanocomposites. The thermal cycling method utilized clinically-relevant conditions pertaining to oral environments, where cold $\left(5{ }^{\circ} \mathrm{C}\right)$ and hot $\left(55^{\circ} \mathrm{C}\right)$ temperatures cause shrinking and expanding of filling restorations. The thermal cycling process utilized here maximized the release of leachate from nanocomposites in a relatively short time period. After 2500 cycles over two weeks, leached AP25 was not detected in any of the evaluated nanocomposites (Ti concentration in nanocomposite specimens (60 mg/L) vs. Ti detection limit $0.007 \mathrm{mg} / \mathrm{L})$ (Tables S1 and S2). This key finding supports the resin polymerization model in which the acrylic acid $\mathrm{C}=\mathrm{C}$ double bond on AP25 forms stable saturated bonds within the cross-linked resin network [11] and locks the AP25 within the nanocomposite. The biocompatibility of nanocomposites containing functionalized $\mathrm{TiO}_{2} \mathrm{NPs}$ in actual cellular environments still needs to be studied, but the absence of significant AP25 leaching suggests that increased levels of DNA lesions are not expected. Furthermore, ROS generation during the dental 
adhesive curing step was statistically insignificant. After bonding, the nanocomposites were in the dark, and as previously described and discussed in this report, DNA base damage is not induced by AP25 nor AceP25, even at the highest exposure doses when the NPs are maintained under dark conditions.

\section{Conclusions}

The ROS generated by irradiating carboxylic acid-functionalized $\mathrm{TiO}_{2} \mathrm{NPs}$ with visible light can be harnessed to specifically enhance the mechanical performance properties of dental adhesives. Realtime monitoring of ROS generation by the NPs with/without carboxylic acid functionalization demonstrated that both the relative quantity and persistence of the generated ROS are increased when the NPs are functionalized by carboxylic acids. After incorporation of the functionalized NPs (AP25) into dental resins, kinetic studies and clinically relevant bonding tests showed that the NPs effectively improved the DC of resins, which further enhanced the bonding of adhesives to teeth. DNA damage analysis revealed a lack of significantly increased lesion levels under light irradiation for $24 \mathrm{~h}$ except at the highest $\mathrm{TiO}_{2} \mathrm{NP}$ concentrations tested $(50 \mathrm{mg} / \mathrm{L})$. Leaching of the NPs from the dental resins was negligible, supporting the potential long-term biocompatibility (e.g. lack of genotoxicity) of these

emerging medical devices. Additional studies testing both the cytotoxicity and genotoxicity of these materials in cell models are warranted.

\section{Acknowledgement}

The authors would like to thank Mr. Anthony Giuseppetti and Dr. Joseph Antonucci for their technical recommendations. One of the authors, CMS, acknowledges funding and support from the National Academy of Sciences - National Research Council Postdoctoral Research Associateship Program. We thank Bharath Natarajan for his assistance in ultramicrotoming the dental resins prior to TEM analysis and Alline F. Myers for her assistance in obtaining STEM/EDS data. We also would like to thank the Center for Nanoscale Science and Technology (CNST) at NIST for their technical support. 


\section{Funding}

This work was funded by the National Institute of Dental and Craniofacial Research (U01DE023752). Financial support was also provided through the American Dental Association Foundation.

\section{NIST Disclaimer}

Certain commercial equipment, instruments and materials are identified in this paper to specify an experimental procedure as completely as possible. In no instance does the identification of particular equipment or materials imply a recommendation or endorsement by the National Institute of Standards and Technology or the American Dental Association Foundation, nor does it imply that the materials, instruments, or equipment are necessarily the best available for the purpose.

\section{List of Acronyms}

3AP = 3-amino-2, 2, 5, 5-tetramethyl-1-pyrrolidinyloxy

$4 \mathrm{E}=$ ethyl 4-N, N-dimethylaminobenzoate

$\mathrm{AA}=$ acrylic acid

$\mathrm{ACP}=$ amorphous calcium phosphate

$\mathrm{AES}=$ Atomic Emission Spectroscopy

ANOVA $=$ one-way Analysis of Variance

AceP25 = titanium dioxide (P25) functionalized by acetic acid

AP25 = titanium dioxide (P25) functionalized by acrylic acid

ATR $=$ attenuated total reflectance

B or Bis-GMA = bisphenol A glycidyl methacrylate

$\mathrm{CQ}=$ camphorquinone

ct-DNA = calf thymus DNA 
$\mathrm{DC}=$ degree of vinyl conversion

$\mathrm{ddH} 2 \mathrm{O}=$ Distilled and deionized water

DLS = dynamic light scattering

$\mathrm{EPR}=$ electron paramagnetic resonance

EDS $=$ energy dispersive spectroscopy

FTIR $=$ Fourier transform infrared

FTIR-RM = FTIR in reflectance mode

FTIR $\mu$ map $=$ Fourier transform infrared microscopic mapping

HR-SEM = high resolution scanning electron microscope

GC/MS/MS = Gas chromatography/tandem mass spectrometry

HEMA or $\mathrm{H}=$ hydroxyethyl-methacrylate

ICP-OES = inductively coupled plasma-optical emission spectroscopy

LSCM = laser scanning confocal microscopy

$\mathrm{wt} \%=$ mass percentage

NIR $=$ near infrared

$\mathrm{NP}=$ nanoparticle

NTA $=$ nitrilotriacetic acid disodium salt

NTG-GMA = Glycine, N-2-hydroxy-3-(2-methyl-1-oxo-2-propenyl)-oxypropyl-N-(4-methylphenyl), monosodium salt [CAS No. 133736-31-9]

$\cdot \mathrm{OH}=$ hydroxyl radical

P25 = titanium dioxide nanoparticles with an average size at $21 \mathrm{~nm}$, provided by Evonik

PMGDM or $\mathrm{P}=$ pyromellitic-glycerol-dimethacrylate

ROS $=$ reactive oxygen species

SBS $=$ shear bond strength

SEM = scanning electron microscopy

SI = supporting information

TBS $=$ tensile bond strength

$\mathrm{T}$ or TEGDMA = triethylene glycol dimethacrylate

$\mathrm{TEM}=$ transmission electron microscopy

TGA $=$ thermogravimetric analysis 
$\mathrm{TiO}_{2}$ NPs = titanium dioxide nanoparticles 


\section{References}

[1] O. Carp, C.L. Huisman, A. Reller, Photoinduced reactivity of titanium dioxide. Prog. Solid State Chem. 32 (2004) 33-177.

[2] X.B. Chen, L. Liu, P.Y. Yu, S.S. Mao, Increasing solar absorption for photocatalysis with black hydrogenated titanium dioxide nanocrystals. Science 331 (2011) 746-750.

[3] B. Oregan, M. Gratzel, A low-cost, high-efficiency solar-cell based on dye-sensitized coloidal $\mathrm{TiO}_{2}$ films. Nature 353 (1991) 737-740.

[4] D. Campoccia, L. Montanaro, C.R. Arciola, A review of the biomaterials technologies for infectionresistant surfaces. Biomaterials 34 (2013) 8533-8554.

[5] G.F. Fu, P.S. Vary, C.T. Lin, Anatase $\mathrm{TiO}_{2}$ nanocomposites for antimicrobial coatings. J. Phys. Chem. B. 109 (2005) 8889-8898.

[6] A. Fujishima, K. Honda, Electrochemical photolysis of water at a semiconductor electrode. Nature 238 (1972) 37-38.

[7] L. Karimi, M.E. Yazdanshenas, R. Khajavi, A. Rashidi, M. Mirjalili, Using graphene/TiO 2 nanocomposite as a new route for preparation of electroconductive, self-cleaning, antibacterial and antifungal cotton fabric without toxicity. Cellulose 21 (2014) 3813-3827.

[8] X.Q. Qiu, M. Miyauchi, K. Sunada, M. Minoshima, M. Liu, Y. Lu, D. Li, Y. Shimodaira, Y. Hosogi, Y. Kuroda, $\mathrm{K}$. Hashimoto, Hybrid $\mathrm{Cu}_{\mathrm{x}} \mathrm{O} / \mathrm{TiO}_{2}$ nanocomposites as risk-reduction materials in indoor environments. ACS Nano 6 (2012) 1609-1618.

[9] Y. Xia, F.M. Zhang, H.F. Xie, N. Gu, Nanoparticle-reinforced resin-based dental composites. J. Dent 36 (2008) 450-455.

[10] J. Sun, S.S. Watson, D.A. Allsopp, D. Stanley, D. Skrtic, Tuning photo-catalytic activities of $\mathrm{TiO}_{2}$ nanoparticles using dimethacrylate resins. Dent. Mater. 32 (2016) 363-372.

[11] J.R. Sun, A.M. Forster, P.M. Johnson, N. Eidelman, G. Quinn, G. Schumacher, X.R. Zhang, W.L. $\mathrm{Wu}$, Improving performance of dental resins by adding titanium dioxide nanoparticles. Dent. Mater. 27 (2011) 972-982.

[12] L.S. Acosta-Torres, L.M. Lopez-Marin, R.E. Nunez-Anita, G. Hernandez-Padron, V.M. Castano, Biocompatible metal-oxide nanoparticles: nanotechnology improvement of conventional prosthetic acrylic resins. J. Nanomater. 2011 (2011) DOI:10.1155/2011/941561.

[13] D. Pinto, L. Bernardo, A. Amaro, S. Lopes, Mechanical properties of epoxy nanocomposites using titanium dioxide as reinforcement - A review. Constr. Build. Mater. 95 (2015) 506-524.

[14] L. Cheng, K. Zhang, M.D. Weir, M.A.S. Melo, X.D. Zhou, H.H.K. Xu, Nanotechnology strategies for antibacterial and remineralizing composites and adhesives to tackle dental caries. Nanomedicine (London) 10 (2015) 627-641. 
[15] R. Song, X.H. Tao, L. Lin, Improvement of mechanical and antimicrobial properties of denture base resin by nano-titanium dioxide and nano-silicon dioxide particles. Pigm. Resi.n Techno.1 40 (2011) 393398.

[16] Q. Li, S. Mahendra, D.Y. Lyon, L. Brunet, M.V. Liga, D. Li, P.J. Alvarez, Antimicrobial nanomaterials for water disinfection and microbial control: potential applications and implications. Water Res. 42 (2008) 4591-4602.

[17] J. De Munck, K. Van Landuyt, M. Peumans, A. Poitevin, P. Lambrechts, M. Braem, B. Van Meerbeek, A critical review of the durability of adhesion to tooth tissue: methods and results. J. Dent. Res. 84 (2005) 118-132.

[18] X.P. Ge, Q. Ye, L.Y. Song, A. Misra, P. Spencer, Synthesis and evaluation of novel siloxanemethacrylate monomers used as dentin adhesives. Dent. Mater. 30 (2014) 1073-1087.

[19] D.H. Pashley, F.R. Tay, L. Breschi, L. Tjaderhane, R.M. Carvalho, M. Carrilho, A. TezvergilMutluay, State of the art etch-and-rinse adhesives. Dent. Mater. 27 (2011) 1-16.

[20] A. Besinis, T. De Peralta, C.J. Tredwin, R.D. Handy, Review of nanomaterials in dentistry: interactions with the oral microenvironment, clinical applications, hazards, and benefits. ACS Nano 9 (2015) 2255-2289.

[21] J. Xiao, W.Q. Chen, F.Y.K. Wang, J.Z. Du, Polymer/TiO ${ }_{2}$ hybrid nanoparticles with highly effective UV-screening but eliminated photocatalytic activity. Macromolecules 46 (2013) 375-383.

[22] M. Rosslein, J.T. Elliott, M. Salit, E.J. Petersen, C. Hirsch, H.F. Krug, P. Wick, Use of cause-andeffect analysis to design a high-quality nanocytotoxicology assay. Chem. Res. Toxicol. 28 (2015) 21-30.

[23] E.J. Petersen, V. Reipa, S.S. Watson, D.L. Stanley, S.A. Rabb, B.C. Nelson, DNA damaging potential of photoactivated P25 titanium dioxide nanoparticles. Chem. Res. Toxicol. 27 (2014) 1877-1884.

[24] L. Armand, A. Tarantini, D. Beal, M. Biola-Clier, L. Bobyk, S. Sorieul, K. Pernet-Gallay, C. MarieDesvergne, I. Lynch, N. Herlin-Boime, M. Carriere, Long-term exposure of A549 cells to titanium dioxide nanoparticles induces DNA damage and sensitizes cells towards genotoxic agents.

Nanotoxicology (2016) 1-11.

[25] E. Demir, H. Akca, F. Turna, S. Aksakal, D. Burgucu, B. Kaya, O. Tokgun, G. Vales, A. Creus, R. Marcos, Genotoxic and cell-transforming effects of titanium dioxide nanoparticles. Environ. Res. 136 (2015) 300-308.

[26] M. Hanot-Roy, E. Tubeuf, A. Guilbert, A. Bado-Nilles, P. Vigneron, B. Trouiller, A. Braun, G. Lacroix, Oxidative stress pathways involved in cytotoxicity and genotoxicity of titanium dioxide $\left(\mathrm{TiO}_{2}\right)$ nanoparticles on cells constitutive of alveolo-capillary barrier in vitro. Toxicol. In Vitro 33 (2016) 125135.

[27] K. Kansara, P. Patel, D. Shah, R.K. Shukla, S. Singh, A. Kumar, A. Dhawan, $\mathrm{TiO}_{2}$ nanoparticles induce DNA double strand breaks and cell cycle arrest in human alveolar cells. Environ. Mol. Mutagen. 56 (2015) 204-217. 
[28] C. Uboldi, P. Urban, D. Gilliland, E. Bajak, E. Valsami-Jones, J. Ponti, F. Rossi, Role of the crystalline form of titanium dioxide nanoparticles: Rutile, and not anatase, induces toxic effects in BALB/3T3 mouse fibroblasts. Toxicol. In Vitro 31 (2016) 137-145.

[29] Y.R. Wang, H.Y. Cui, J.P. Zhou, F.J. Li, J.J. Wang, M.H. Chen, Q.D. Liu, Cytotoxicity, DNA damage, and apoptosis induced by titanium dioxide nanoparticles in human non-small cell lung cancer A549 cells. Environ. Sci. Pollut. Res. Int. 22 (2015) 5519-5530.

[30] A. Zijno, I. De Angelis, B. De Berardis, C. Andreoli, M.T. Russo, D. Pietraforte, G. Scorza, P. Degan, J. Ponti, F. Rossi, F. Barone, Different mechanisms are involved in oxidative DNA damage and genotoxicity induction by $\mathrm{ZnO}$ and $\mathrm{TiO}_{2}$ nanoparticles in human colon carcinoma cells. Toxicol. In Vitro 29 (2015) 1503-1512.

[31] E.J. Petersen, B.C. Nelson, Mechanisms and measurements of nanomaterial-induced oxidative damage to DNA. Anal. Bioanal. Chem. 398 (2010) 613-650.

[32] D.Q. Vo, E.J. Kim, S. Kim, Surface modification of hydrophobic nanocrystals using short-chain carboxylic acids. J. Colloid Interface Sci. 337 (2009) 75-80.

[33] J.S. Taurozzi, V.A. Hackley, M.R. Wiesner, A standardised approach for the dispersion of titanium dioxide nanoparticles in biological media. Nanotoxicology 7 (2013) 389-401.

[34] D.E. Koppel, Analysis of macromolecular polydispersity in intensity correlation spectroscopy method of cumulants. J. Chem. Phys. 57 (1972) 4814-4820.

[35] J. Riseman, J.G. Kirkwood, The intrinsic viscosity, translational and rotatory diffusion constants of rod-like macromoleculres in solution. J. Chem. Phys. 18 (1950) 512-516.

[36] O.I. Aruoma, B. Halliwell, E. Gajewski, M. Dizdaroglu, Copper-ion-dependent damage to the bases in DNA in the presence of hydrogen peroxide. Biochem J 273 ( Pt 3) (1991) 601-604.

[37] D.H. Atha, H. Wang, E.J. Petersen, D. Cleveland, R.D. Holbrook, P. Jaruga, M. Dizdaroglu, B. Xing, B.C. Nelson, Copper oxide nanoparticle mediated DNA damage in terrestrial plant models. Environ. Sci. Technol. 46 (2012) 1819-1827.

[38] P.R. Hunt, B.J. Marquis, K.M. Tyner, S. Conklin, N. Olejnik, B.C. Nelson, R.L. Sprando, Nanosilver suppresses growth and induces oxidative damage to DNA in Caenorhabditis elegans. J. App. Toxicol. 33 (2013) 1131-1142.

[39] E.J. Petersen, X. Tu, M. Dizdaroglu, M. Zheng, B.C. Nelson, Protective roles of single-wall carbon nanotubes in ultrasonication-induced DNA base damage. Small 9 (2013) 205-208.

[40] J.W. Stansbury, S.H. Dickens, Determination of double bond conversion in dental resins by near infrared spectroscopy. Dent. Mater. 17 (2001) 71-79.

[41] N. Eidelman, D. Raghavan, A.M. Forster, E.J. Amis, A. Karim, Combinatorial approach to characterizing epoxy curing. Macromol. Rapid Commun. 25 (2004) 259-263.

[42] J.M. Antonucci, B.O. Fowler, M.D. Weir, D. Skrtic, J.W. Stansbury, Effect of ethyl-alphahydroxymethylacrylate on selected properties of copolymers and ACP resin composites. J. Mater. Sci.Mater. Med. 19 (2008) 3263-3271. 
[43] Q.A. Ye, Y. Wang, K. Williams, P. Spencer, Characterization of photopolymerization of dentin adhesives as a function of light source and irradiance. J. Biomed. Mater. Res. Part B 80B (2007) 440-446.

[44] L.Y. Song, Q. Ye, X.P. Ge, A. Misra, J.S. Laurence, C.L. Berrie, P. Spencer, Synthesis and evaluation of novel dental monomer with branched carboxyl acid group. J. Biomed. Mater. Res. Part B 102 (2014) 1473-1484.

[45] X.P. Ge, Q. Ye, L.Y. Song, A. Misra, P. Spencer, Visible-light initiated free-radical/cationic ringopening hybrid photopolymerization of methacrylate/epoxy: polymerization kinetics, crosslinking structure, and dynamic mechanical properties. Macromol. Chem. Phys. 216 (2015) 856-872.

[46] X.P. Ge, Q. Ye, L.Y. Song, J.S. Laurence, P. Spencer, Synthesis and evaluation of a novel coinitiator for dentin adhesives: polymerization kinetics and leachables study. JOM 67 (2015) 796-803.

[47] L.A. Hussain, S.H. Dickens, R.L. Bowen, Shear bond strength of experimental methacrylated betacyclodextrin-based formulations. Biomaterials 26 (2005) 3973-3979.

[48] S.H. Dickens, M.F. Milos, Relationship of dentin shear bond strengths to different laboratory test designs. Am. J. Dent. 15 (2002) 185-192.

[49] J. De Munck, B. Van Meerbeek, Y. Yoshida, S. Inoue, M. Vargas, K. Suzuki, P. Lambrechts, G. Vanherle, Four-year water degradation of total-etch adhesives bonded to dentin. J. Dent. Res. 82 (2003) 136-140.

[50] H. Hosoda, T. Yamada, S. Inokoshi, SEM and elemental analysis of composite resins. J. Prosthet. Dent. 64 (1990) 669-676.

[51] V. Geertsen, M. Tabarant, O. Spalla, Behavior and determination of titanium dioxide nanoparticles in nitric acid and river water by ICP spectrometry. Anal. Chem. 86 (2014) 3453-3460.

[52] F.R. Tay, D.H. Pashley, R.R. Kapur, M.R.O. Carrilho, Y.B. Hur, L.V. Garrett, K.C.Y. Tay, Bonding BisGMA to dentin - a proof of concept for hydrophobic dentin bonding. J. Dent. Res. 86 (2007) 10341039.

[53] Y. Nishitani, M. Yoshiyama, A.M. Donnelly, K.A. Agee, J. Sword, F.R. Tay, D.H. Pashley, Effects of resin hydrophilicity on dentin bond strength. J. Dent. Res. 85 (2006) 1016-1021. 


\section{Tables}

Table 1: Comparing the photoactivities of the three types of $\mathrm{TiO}_{2} \mathrm{NPs},[\mathrm{NP}]=1000 \mathrm{mg} / \mathrm{L}$.

\begin{tabular}{|l|c|c|c|c|c|}
\hline \multirow{2}{*}{} & \multicolumn{3}{|c|}{ Linear fit (0s-750 s)* } & \multicolumn{2}{c|}{ EPR signal (> 1000 s) } \\
\cline { 2 - 6 } & Slope (\%/s) & STDEV & R-square & Average (\%) & STDEV (\%) \\
\hline 3AP only & -0.0014 & $1.9 \mathrm{E}-4$ & 0.999 & 98.8 & 1.4 \\
\hline 3AP+P25 & -0.0896 & 0.0018 & 0.998 & 34.3 & 3.9 \\
\hline 3AP+AP25 & -0.1007 & 0.0019 & 0.998 & 27.2 & 3.7 \\
\hline 3AP+AceP25 & -0.1097 & 0.0027 & 0.995 & 23.1 & 4.9 \\
\hline
\end{tabular}

Note: *Intercept was set at $(0,100)$. 


\section{Figure Captions}

Figure 1. Characterization of functionalized $\mathrm{TiO}_{2}$ NPs: (A) FTIR spectra, (B) TGA spectra showing normalized mass and $(\mathrm{C})$ the derivative of mass \% change $(\mathrm{C})$.

Figure 2. EPR evaluation of NP powders (A, B) and their aqueous suspensions (C, D). (A) Relative ROS production from NP powders as a function of time under light exposure. (B) EPR spectra of NP powders after $1 \mathrm{~h}$ of light exposure. (C) Normalized EPR signal changes as a function of light exposure time in the presence of the spin trapping agent (3AP) at $0 \mathrm{mg} / \mathrm{L}, 50 \mathrm{mg} / \mathrm{L}$ (with and without light exposure) and 1000 mg/L P25. (D) Normalized EPR signal changes as a function of visible-light exposure time in the presence of $3 \mathrm{AP}$ and $1000 \mathrm{mg} / \mathrm{L}$ of different NPs.

Figure 3. DNA damage profile for ct-DNA exposed to increasing concentrations of AP25 (0.5 mg/L to 50 $\mathrm{mg} / \mathrm{L})$ in the dark (A) or under visible light irradiation $\left(24 \mathrm{~h}\right.$ exposure; total irradiance $=1600 \mathrm{~mW} / \mathrm{cm}^{2}$, $400 \mathrm{~nm}$ to $800 \mathrm{~nm})(B)$. Number signs $\left(^{\#}\right)$ indicate statistically significant decreases and asterisks $\left(^{*}\right)$ indicate statistically significant increases in measured lesions levels compared to the control samples using ANOVA followed by Dunnett's multiple comparison test. Data was log transformed prior to statistical testing. One, three or four number of signs/asterisks indicate $\mathrm{p}<0.05,0.001$ and 0.0001 , respectively. All data points represent the mean of 5 to 6 independent measurements. Uncertainties are standard deviations.

Figure 4. DNA damage profile for ct-DNA exposed to increasing concentrations of AceP25 (0.5 mg/L to $50 \mathrm{mg} / \mathrm{L})$ in the dark (A) or under visible light irradiation $\left(24 \mathrm{~h}\right.$ exposure; total irradiance $=1600 \mathrm{~mW} / \mathrm{cm}^{2}$, $400 \mathrm{~nm}$ to $800 \mathrm{~nm})(B)$. Number signs $\left(^{\#}\right)$ indicate statistically significant decreases and asterisks $\left(^{*}\right)$ indicate statistically significant increases in measured lesions levels compared to the control samples using ANOVA followed by Dunnett's multiple comparison test. Data was log transformed prior to 
statistical testing. One, two, three or four number signs/asterisks indicate $\mathrm{p}<0.05,0.01,0.001$ and 0.0001, respectively. All data points represent the mean of 5 to 6 independent measurements. Uncertainties are standard deviations.

Figure 5. (A) Bright-field TEM image of $\mathrm{TiO}_{2}$ NPs within the dental resin. (B) EDS spectrum of the area shown in (A). Note the characteristic $\mathrm{K} \alpha$ and $\mathrm{K} \beta$ lines at 4.51 and $4.92 \mathrm{keV}$ respectively, indicating the presence of $\mathrm{Ti}$. The $\mathrm{Cu}$ signal is from the copper grid and the Si signal is from remnants of the glass knife used to prepare the sections. (C) Lattice fringe image of a single AP25 particle within the dental resin. (D) $d$-spacing line profile over a portion of the AP25 particle shown in (C). Note the indicated $d$-spacing of $0.355 \mathrm{~nm}$, consistent with the (101) plane of the anatase form of $\mathrm{TiO}_{2}$.

Figure 6. Degree of vinyl conversion (\% DC) of three resin mixtures compared to the nanocomposites containing AP25. Data is shown from $50 \%$ DC and higher to illustrate DC differences between each resin mixture and its corresponding nanocomposite. The mean increase in nanocomposite DC values was $\approx 7 \%$ (across all 3 types of nanocomposites). All data represent the mean of 5 measurements $(\mathrm{n}=5)$. Two asterisks indicate $\mathrm{p}<0.01$. Uncertainties are standard deviations.

Figure 7. Mean value \pm standard deviation of the SBS attained across all three types $(\mathrm{B} / \mathrm{T}(1 / 1), \mathrm{B} / \mathrm{H}$ (1/1), P/H (1/1)) of adhesive resins combined. For resins (no AP25), $\mathrm{n}=14$ data points comprised of $4 \mathrm{~B} / \mathrm{H}+5 \mathrm{~B} / \mathrm{T}+5 \mathrm{P} / \mathrm{H}$ measurements. For resins (with AP25), $\mathrm{n}=14$ data points comprised of $5 \mathrm{~B} / \mathrm{H}+5$ $\mathrm{B} / \mathrm{T}+4 \mathrm{P} / \mathrm{H}$ measurements. Commercial adhesive Scotchbond was used as a control $(n=5)$. Asterisk indicates $\mathrm{p}<0.05$. Uncertainties are standard deviations.

Figure 8. SEM image showing penetration of dental adhesive into resin tubules. Left column: dental adhesive made with pure resin $(\mathrm{B} / \mathrm{T}=1 / 1)$ with increased magnification; right column: dental adhesive made with the corresponding nanocomposites $(\mathrm{B} / \mathrm{T}=1 / 1, \mathrm{AP} 251000 \mathrm{mg} / \mathrm{L})$ with increased magnification. 

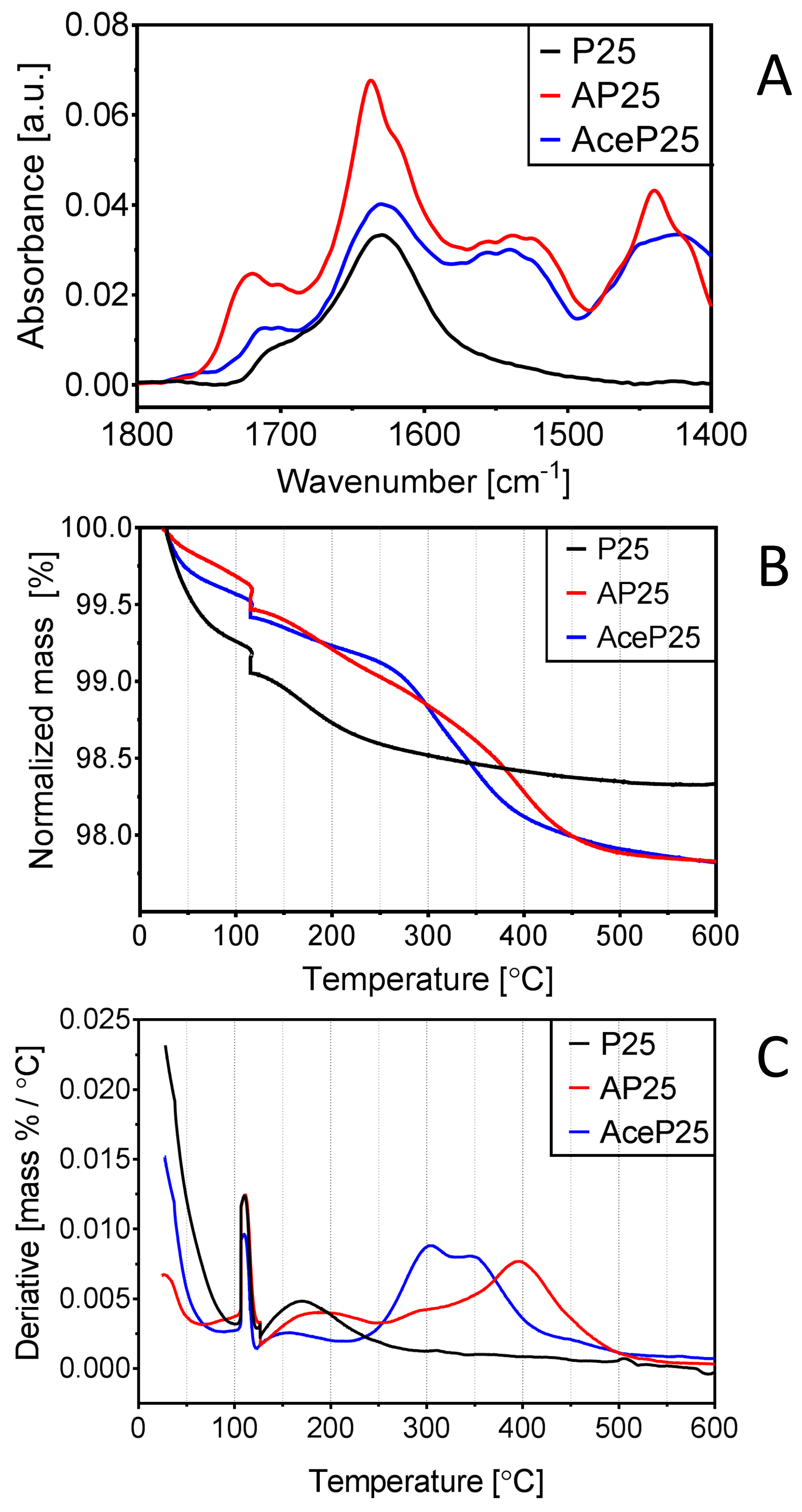

B 

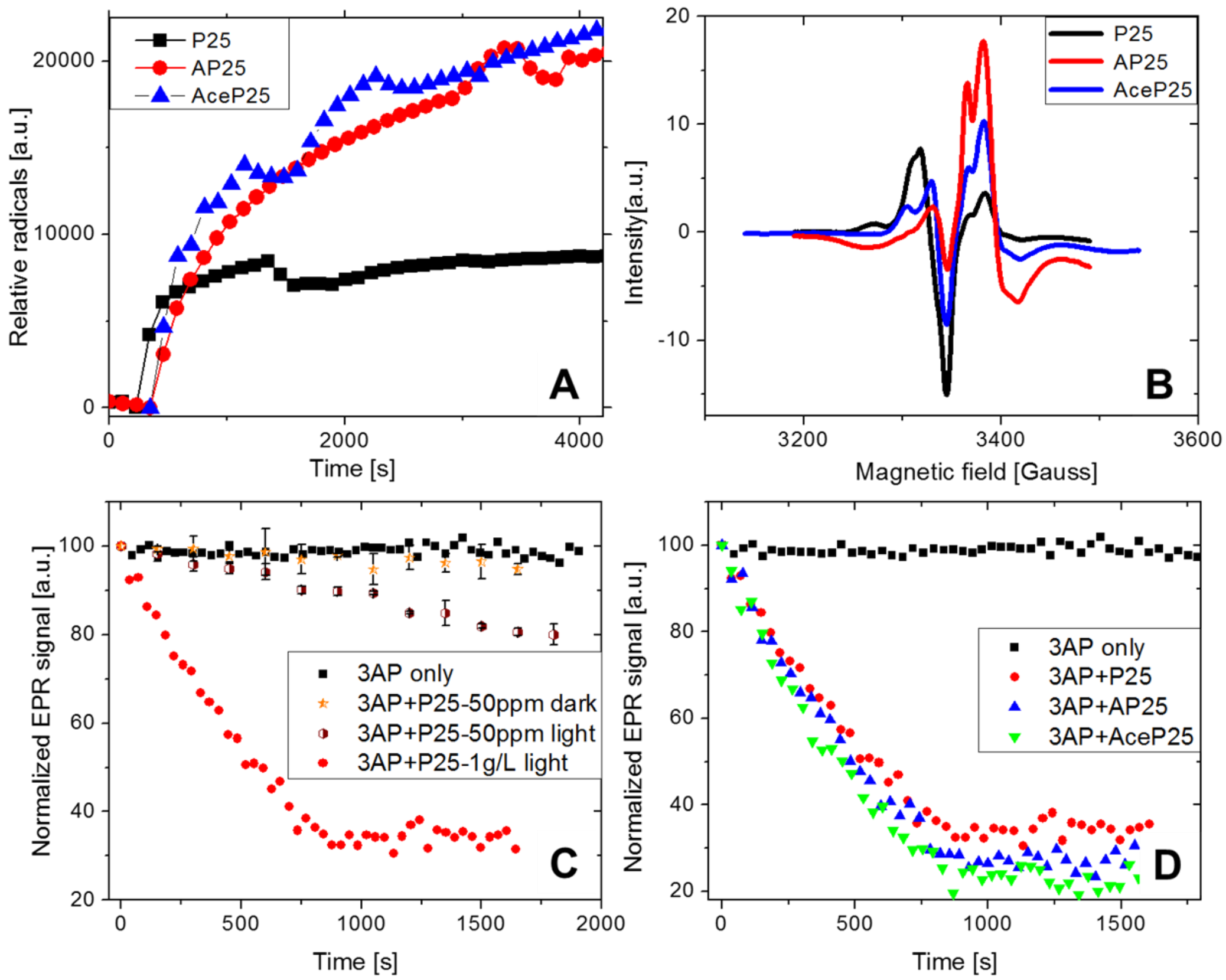
Negative Control

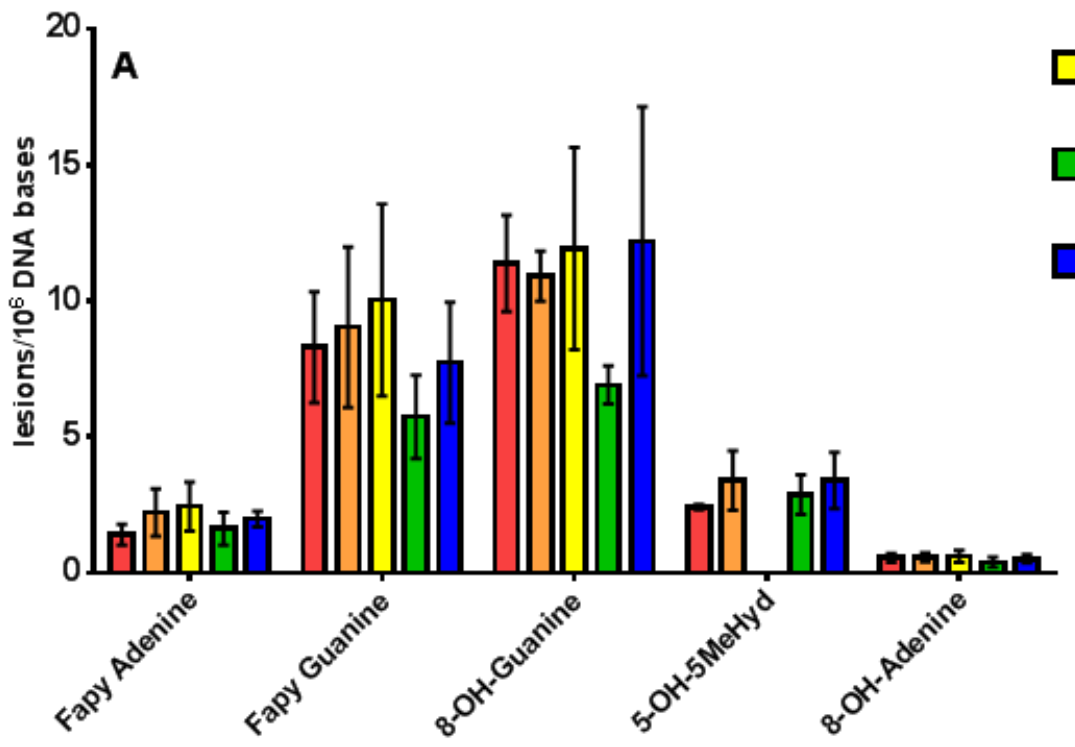

$0.5 \mathrm{mg} / \mathrm{L} \mathrm{AP} 25 \mathrm{NP}$

$5.0 \mathrm{mg} / \mathrm{L} \mathrm{AP25} \mathrm{NP}$

$50.0 \mathrm{mg} / \mathrm{L}$ AP25NP

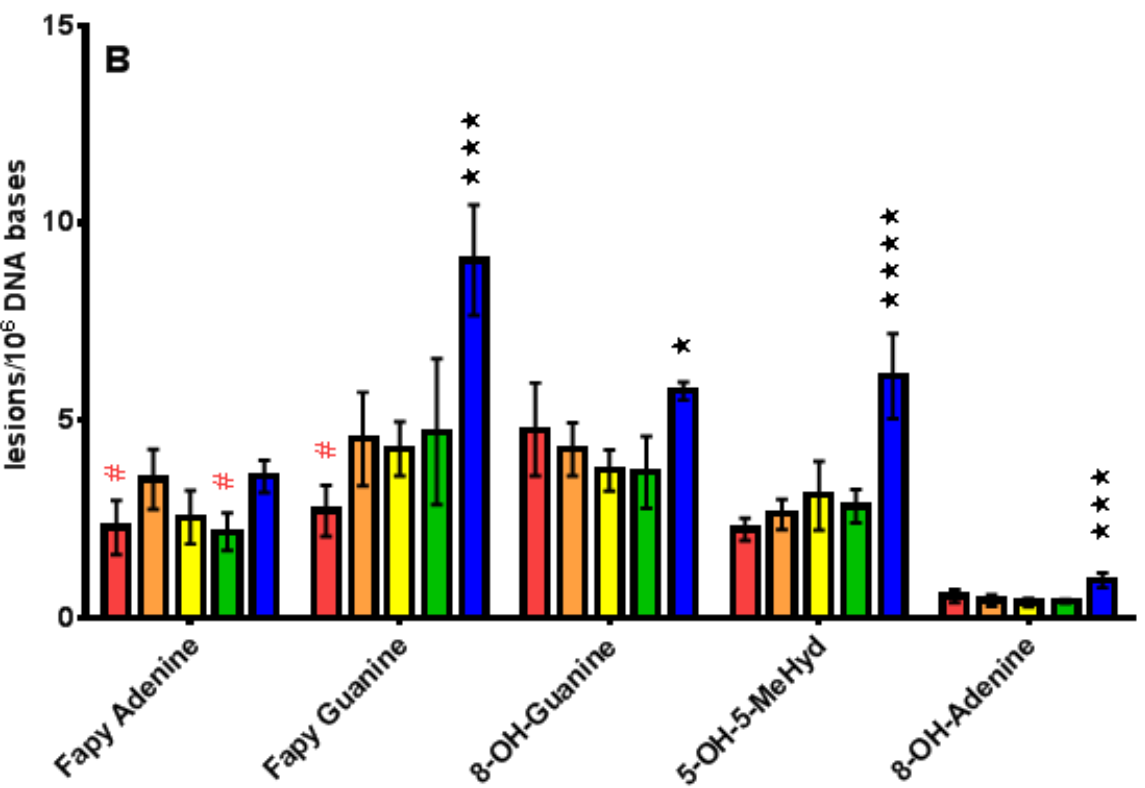


Acetic Acid Ligand Control

Negative Control
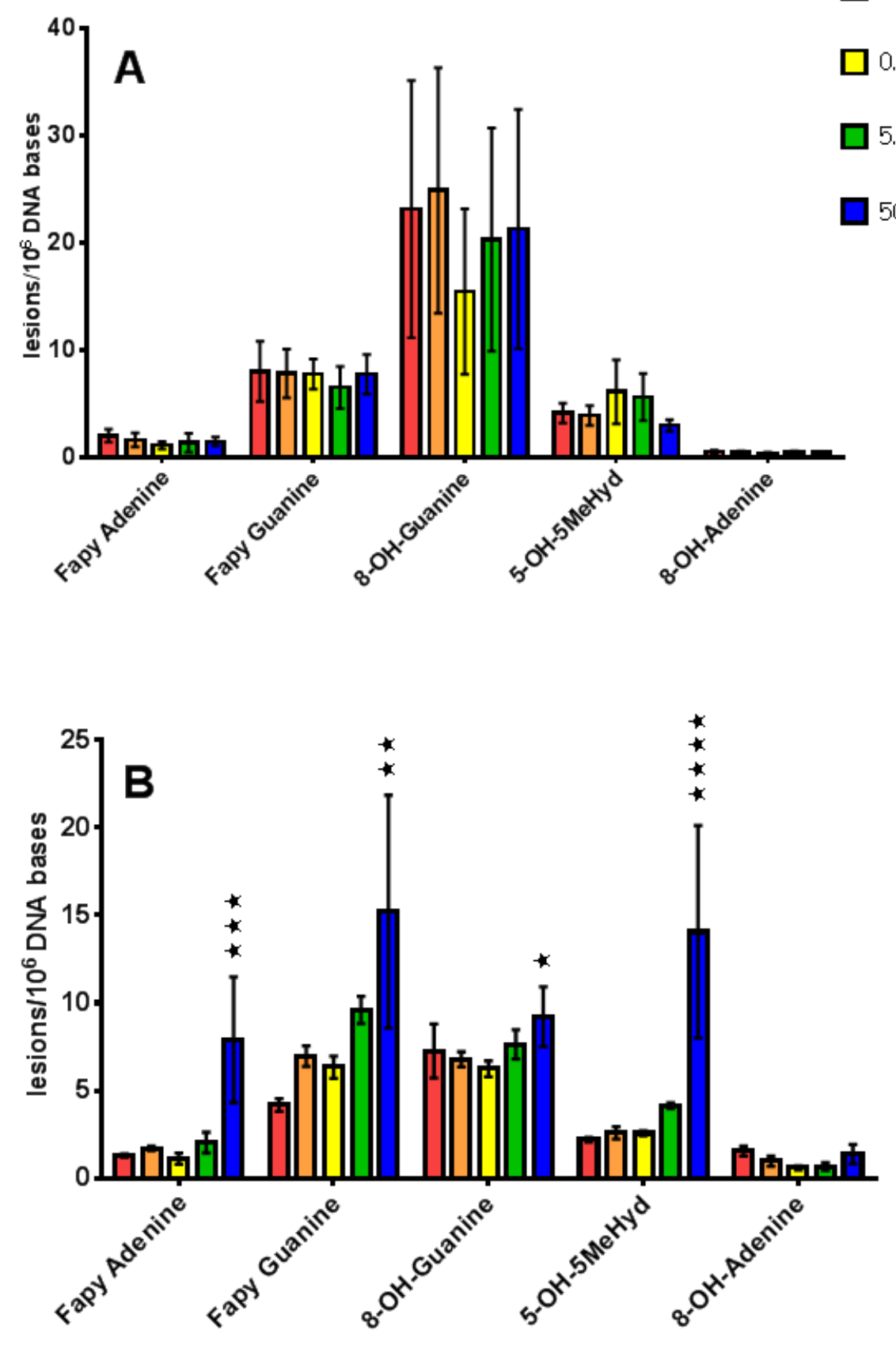

$0.5 \mathrm{mg} / \mathrm{L}$ AceP $25 \mathrm{NP}$

$5.0 \mathrm{mg} / \mathrm{L} \mathrm{AceP} 25 \mathrm{NP}$

$50.0 \mathrm{mg} / \mathrm{L}$ AceP25 NP$$
<
$$

$$
\text { 西 }
$$



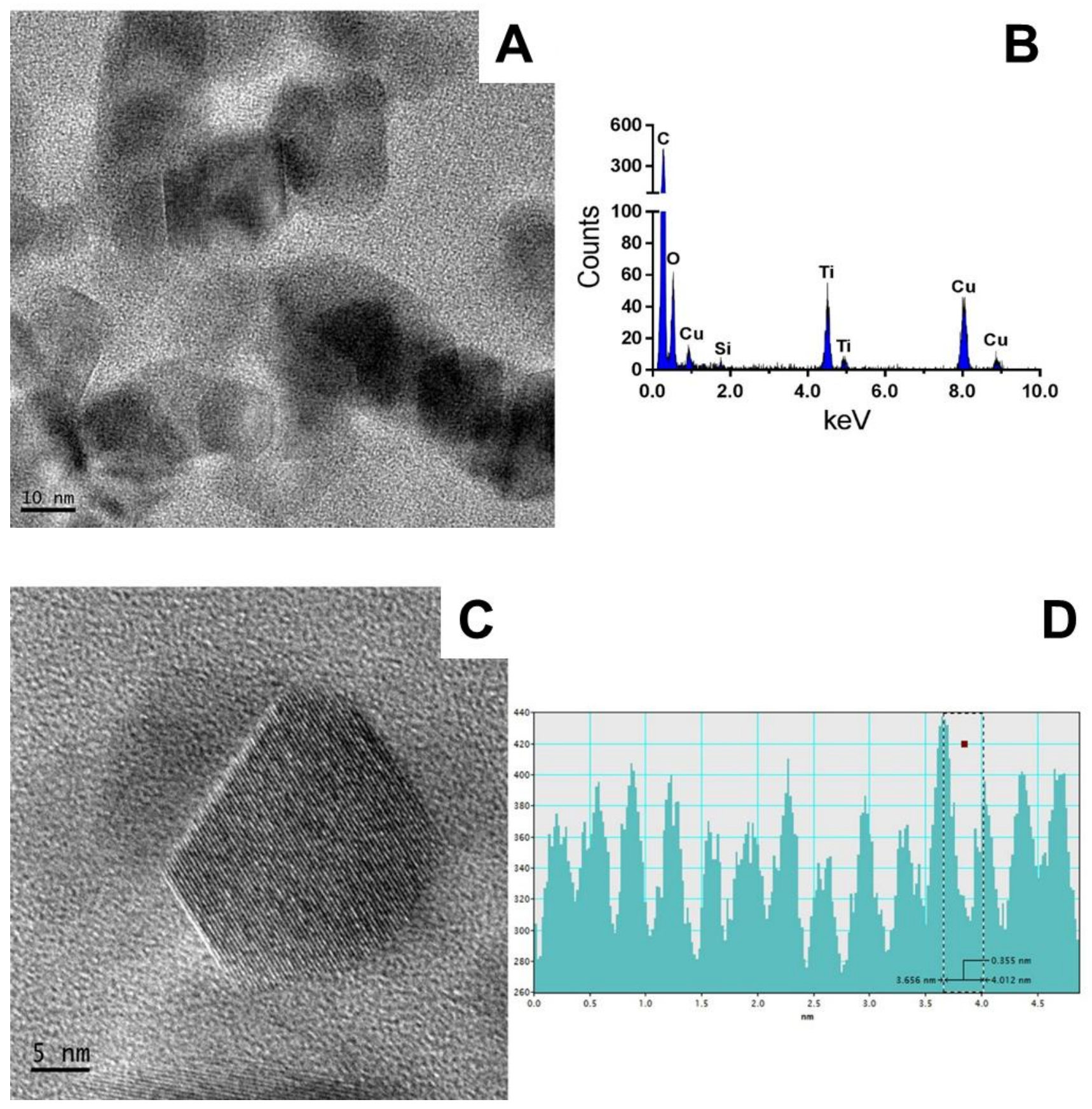

$5 \mathrm{~nm}$ 


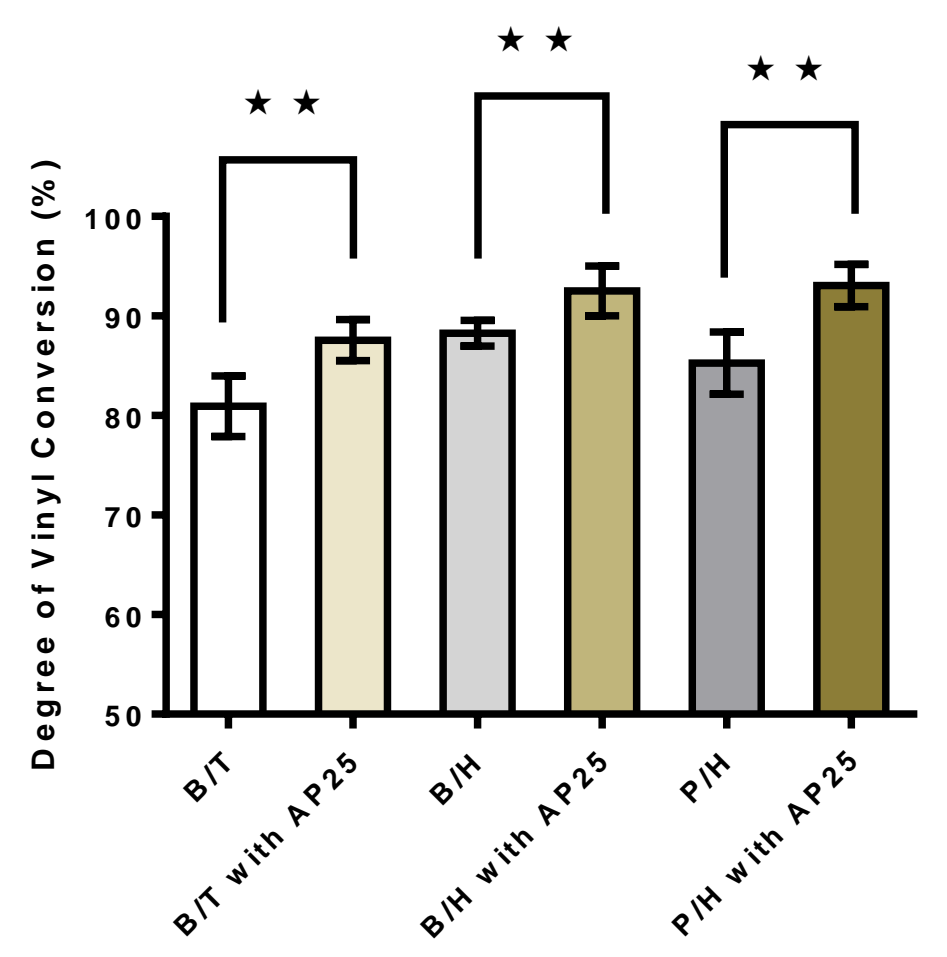




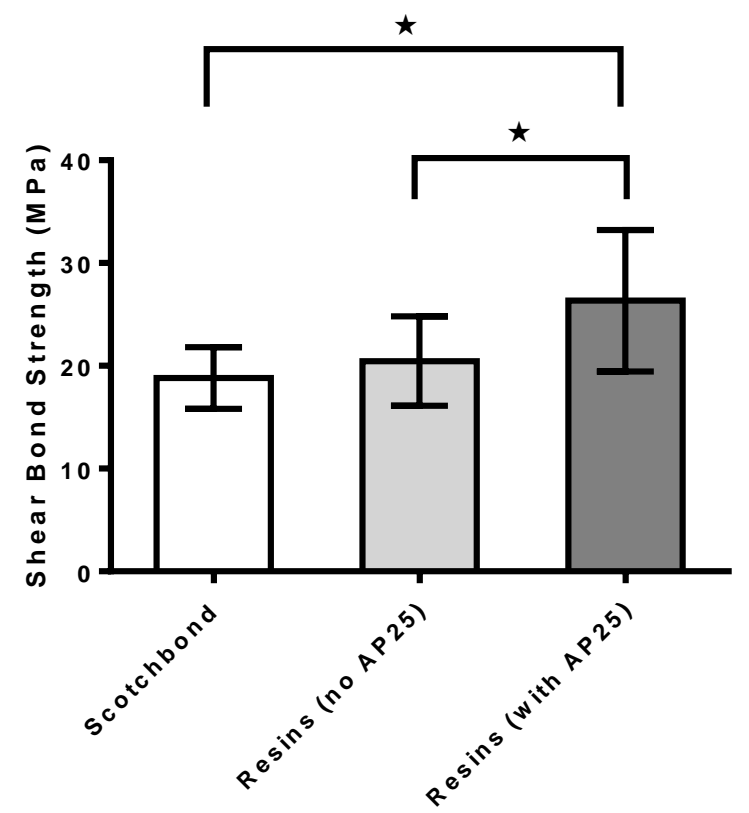


$B+T$
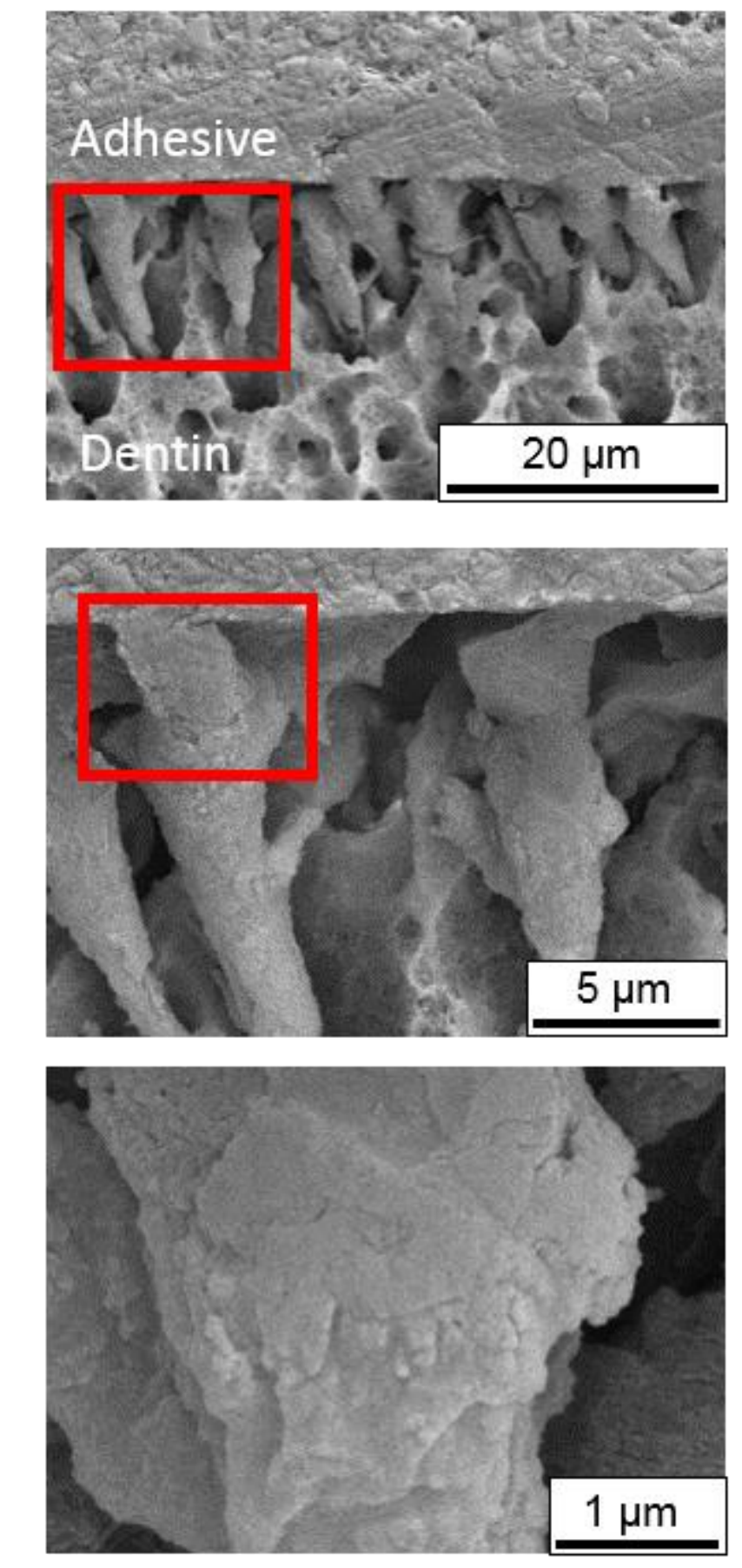

$\mathrm{B}+\mathrm{T}+0.1 \% \mathrm{TiO}_{2}$
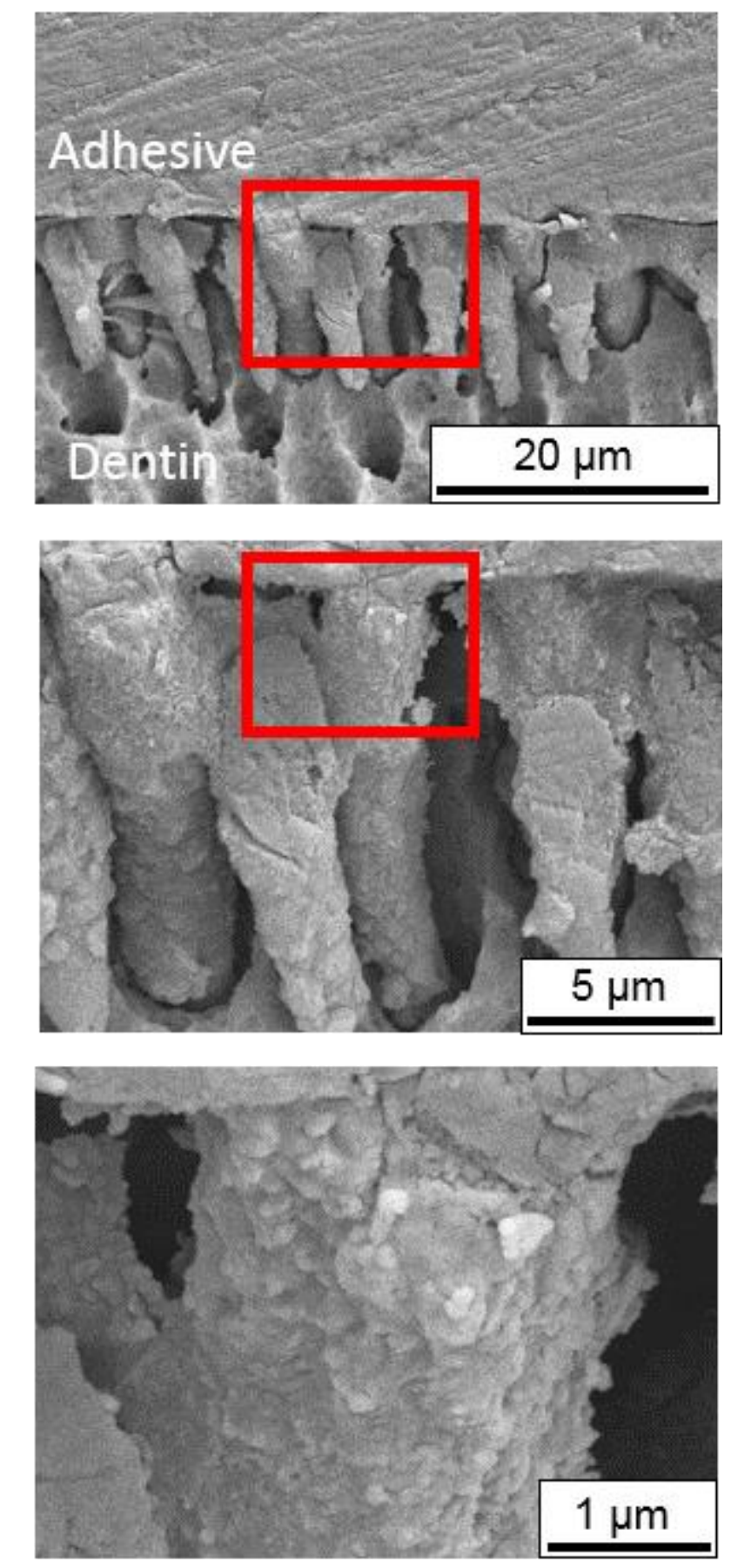


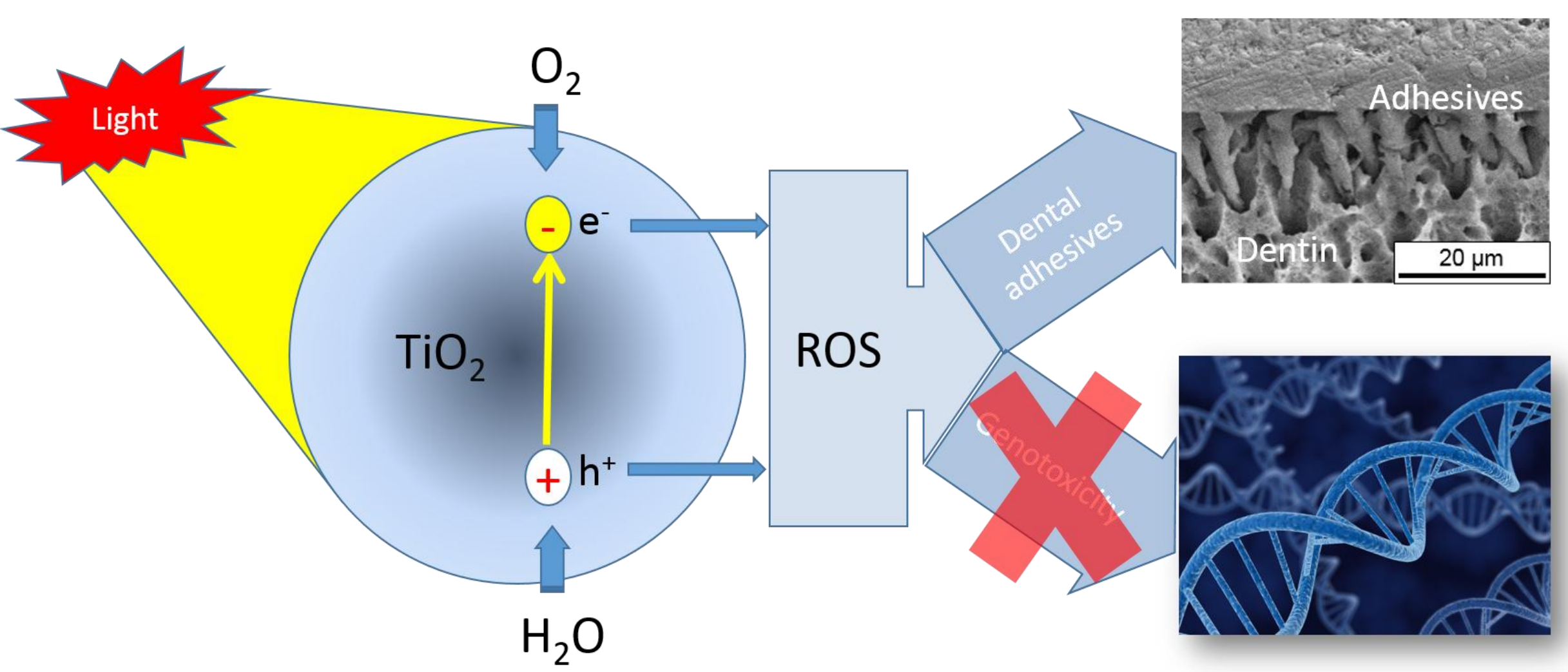




\section{Biophysical Characterization of Functionalized Titania Nanoparticles and Their Application in Dental Adhesives}

Jirun Sun ${ }^{1 *}$, Elijah J. Petersen ${ }^{2}$, Stephanie S. Watson ${ }^{3}$, Christopher M. Sims ${ }^{2}$, Alexander Kassman ${ }^{1}$, Stanislav Frukhtbeyn ${ }^{1}$, Drago Skrtic ${ }^{1}$, Meryem T. Ok ${ }^{2}$, Debbie L. Jacobs ${ }^{3}$, Vytas Reipa ${ }^{2}$, Qiang Ye ${ }^{4}$, and Bryant C. Nelson ${ }^{2 *}$

1. Volpe Research Center, American Dental Association Foundation, Gaithersburg, MD 20899, USA

2. Biosystems and Biomaterials Division, Material Measurement Laboratory, National Institute of Standards and Technology, Gaithersburg, MD 20899, USA

3. Polymeric Materials Group, Materials and Structural Systems Division, Engineering Laboratory, National Institute of Standards and Technology, Gaithersburg, MD 20899, USA

4. Bioengineering Research Center, University of Kansas, Lawrence, Kansas 66045, USA

* To whom correspondence should be addressed:

bryant.nelson@nist.gov

$\underline{301-975-2517(\mathrm{ph}) ; 301-975-8542(\text { fax })}$

jirun.sun@nist.gov

$\underline{301-975-5439(\mathrm{ph})}$ 


\section{Statement of Significance}

Titanium dioxide nanoparticles $\left(\mathrm{TiO}_{2} \mathrm{NPs}\right)$ have unique photocatalytic, antibacterial and UV-absorbing properties that make them beneficial additives in adhesives and composites. However, there is concern that the reactive oxygen species (ROS) produced by photoactivated $\mathrm{TiO}_{2} \mathrm{NPs}$ might pose toxicological risks. We demonstrate that it is possible to incorporate acid-functionalized $\mathrm{TiO}_{2} \mathrm{NPs}$ into dental resins which can be applied as dental adhesives to human teeth. The ROS generated by these NPs through visible-light irradiation may be utilized to increase the degree of vinyl conversion of resins, leading to adhesives that have an enhanced shear-bond strength to human teeth. Investigation into the potential genotoxicity of the NPs and their potential for release from dental composites indicated a low risk of genotoxic effects. 